\title{
An Implementation of IoT and Data Analytics in Smart Agricultural System - A Systematic Literature Review
}

\author{
K. Vikranth ${ }^{1,2}$ \& Krishna Prasad K. ${ }^{3}$ \\ ${ }^{1}$ Research Scholar, College of Computer Science and Information Science, Srinivas \\ University, Mangaluru, Karnataka, India \\ ${ }^{2}$ Assistant Professor, Department of Computer Science, Vivekananda College, Puttur, India \\ Orcid ID: 0000-0001-9549-1743; Email: vikranth.kadya@gmail.com \\ ${ }^{3}$ Professor, College of Computer Science \& Information Science, Srinivas University, \\ Mangaluru, Karnataka, India \\ Orcid ID: 0000-0001-5282-9038; Email: krishnaprasadkcci@srinivasuniversity.edu.in
}

Area/Section: Business Management.

Type of the Paper: Review Paper.

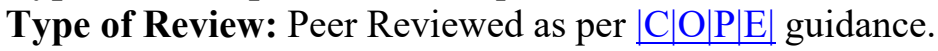

Indexed in: OpenAIRE.

DOI: http://doi.org/10.5281/zenodo.4496828

Google Scholar Citation: IJMTS.

\section{How to Cite this Paper:}

Vikranth, K., \& Krishna Prasad, K. (2021). An Implementation of IoT and Data Analytics in Smart Agricultural System - A Systematic Literature Review. International Journal of Management, Technology, and Social Sciences (IJMTS), 6(1), 41-70. DOI: http://doi.org/10.5281/zenodo.4496828.

International Journal of Management, Technology, and Social Sciences (IJMTS) A Refereed International Journal of Srinivas University, India.

(C) With Author.

CrossRef DOI: https://doi.org/10.47992/IJMTS.2581.6012.0129

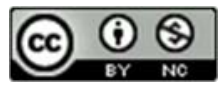

This work is licensed under a Creative Commons Attribution-Non-Commercial 4.0 International License subject to proper citation to the publication source of the work.

Disclaimer: The scholarly papers as reviewed and published by the Srinivas Publications (S.P.), India are the views and opinions of their respective authors and are not the views or opinions of the SP. The SP disclaims of any harm or loss caused due to the published content to any party. 


\title{
An Implementation of IoT and Data Analytics in Smart Agricultural System - A Systematic Literature Review
}

\author{
K. Vikranth ${ }^{1,2}$ \& Krishna Prasad K. ${ }^{3}$ \\ ${ }^{1}$ Research Scholar, College of Computer Science and Information Science, Srinivas \\ University, Mangaluru, Karnataka, India \\ ${ }^{2}$ Assistant Professor, Department of Computer Science, Vivekananda College, Puttur, India \\ Orcid ID: 0000-0001-9549-1743; Email: vikranth.kadya@gmail.com \\ ${ }^{3}$ Professor, College of Computer Science \& Information Science, Srinivas University, \\ Mangaluru, Karnataka, India \\ Orcid ID: 0000-0001-5282-9038; Email: krishnaprasadkcci@srinivasuniversity.edu.in
}

\begin{abstract}
India is a country that depends on agriculture, where about half the population relies heavily on agriculture for their livelihood. However, most of the practices undertaken in the agricultural process are not for profit and yield favorable. It should upgrade with current technologies to boost seed quality, check soil infertility, check the water level, environmental changes, and market price prediction, and achieve in agriculture sensitivity of faults and background understanding. The advancement in technology and developments is seen as a significant aspect in their financial development and agricultural production growth. The Internet of Things (IoT), Wireless Sensor Networks (WSN), and data analytics accomplish these upgrades. These technologies help in providing solutions to agricultural issues such as resource optimization, agricultural land monitoring, and decision-making support, awareness of the crop, land, weather, and market conditions for farmers. Smart agriculture is based on data from sensors, data from cloud platform storage and data from databases, all three concepts need to be implemented. The data are collected from different sensors and stored in a cloud-based back end support, which is then analyzed using proper analytics techniques, and then the relevant information is transferred to a user interface, which naturally supported the decision to conclude. The IoT applications mainly use sensors to monitor the situation, which collects a large size of data every time, so in the case of the Internet of Things (IoT) application, sensors contribute more. Data analytics requires data storage, data aggregation, data processing and data extraction. To retrieve data and information from database, we must use data mining techniques. It acts a significant position in the selection-making process on several agricultural issues. The eventual objective of data mining is to acquire information form data transform it for some advanced use into a unique human-comprehensible format. Big data's role in Agriculture affords prospect to increase the farmers' economic gain by undergoing a digital revolution in this aspect that we examine with precision. This paper includes reviewing a summary of some of the conference papers, journals, and books that have been going in favor of smart agriculture. The type of data required for smart farming system are analyzed and the architecture and schematic diagram of a proposed intelligent farming system are included. It also involves implementing different components of the smart farming system and integrating IoT and data analytics in the smart farming system. Based on the review, research gap, research agendas to carry out further research are identified.
\end{abstract}

Keywords: IoT, Internet of Things, Data analytics, Big data, WSN, BDA, Smart agriculture, Hadoop, Map reduce.

\section{INTRODUCTION :}

Agriculture in India was ranked second in the world, contributing to Indian Gross Domestic Product (GDP) in 2014 by more than 13 percent. It also gives the labor force to more than 50 percent of the 
Indian population. In India, agriculture is one of the broadest sectors contributing to the Indian's economy, culture and social domicile. The current methodologies and practices used in the system of agriculture trails the sector in all dimensions. By 2050, the entire population of the world reaches nearly 10 billion, so we should ask ourselves some research questions about food safety and agricultural production [1]. To meet these requirements, agricultural production must increase by 60 percent. It is not sufficient and consistent to achieve that the traditional method of agriculture. In addition, now some experts are starting to incorporate innovations to combine with the practice of agriculture with the idea of low costs and better performance. IoT and Data Analytics play a significant role in agriculture as a result that it leads innovations such as Wireless Sensor Networks (WSNs). The development of technology and global networking helps agriculture solve problems systematically and it gives the label of IT agriculture or smart farming. Sensors also play a crucial role here, gathering various crop information such as information on moisture, insect information, whether information, data on water level, soil information and field information. To collect all this information, various types of sensors such as moisture sensors, electromagnetic sensors, and optical sensors need to be used. Such sensorenabled devices produce a big sized data that can be placed in a different storage system or cloud database. Agricultural big data solutions include technologies such as Hadoop Distributed File System (HDFS), Map Reduce, STORM and so on. So if we implement all of these technologies in agriculture, it will reduce crop failure and satisfy farmers' primary concern to generate a profit. Adopting these technologies enhances the farming cycle by optimizing the efficiency and reducing environmental effects. This also helps farmers in how much fertilizer to use, and water requirement, and pesticide and insecticide information [2]. Wireless Sensor Network (WSN) is a state-of-the-art technology comprised of sensor comprehension, mechanization manage, digital network transmission, information storage, and information dispensation to provide effective solutions for a target range of farm applications. The efficiency, productivity, and profitability of many agricultural production systems by using the Wireless Sensor Networks (WSNs) would increase precision agriculture. With the aid of the wireless network, IoT helps farmers with live updates by informing people about the crops. We can connect different sensors such as sensors for temperature, sensors for moisture, sensors for water level, and sensors for flood gauge. With the aid of these different sensors, this can provide the farmer with conscious notifications about what is continuing in the field [3]. The development of wireless communication technology leads to improvements in relatively low cost, less power consumption and small-scale multifunctional sensors that allow short-range communication [4]. IoT's architecture consisted of 3 strata. The front end layer gathers information about the environment generated by various agricultural activities. The middle layer acts as a layer of the gateway that connects the front end layer to the Internet. The back end layer stores all the front end data collected [5]. Collectively, the sensor nodes are useful to transmit the précised data to the sink, called a bottom station to screen and extent a conclusion about an atmosphere. The base station does the interpretation of the discoveries on the data collected [6]. The word big data refer to the large number of data sets available. Sensors, phones, and other devices are all producing big data. The primary goal of acquiring such large data source is to use efficient processing to search for meaningful patterns. The big data collected using different sensors that undergo several phases of arrangement, dispensation, and organization into significant information that can later be analyzed for proper decision-making. Sensors are a critical part of Big Data [7]. It's a procedure of inspecting uncovered arrangements, discovery an unknown correlation, and result useful evidence accepted for analyzing decision-making. The IoT and data analytics focused on fields such as agricultural production forecasting, manufacturing forecasting, machine learning algorithms, the forecast of failure, predictive preservation, supply chain management, recurrent pattern mining. The sensor tracks soil nutrients, humidity levels, weather tracking and pest detection in smart agriculture. With these principles, we can farm sustainable without water wasting and reduce fertilizer use. The farmers are insisted on using the mobile application in which they obtain the results of the study and can decide to make productive agriculture on the basis of the result [8]. This paper focused primarily on the proposed smart farming architecture, using wireless sensor networks and big data analytics. In addition, they also reviewed some technologies used to process big data and put into practice techniques for data analytics.

\section{RESEARCH OBJECTIVES :}


Our research area is on data analytics by using Wireless Sensor Network (WSN), IoT and existing dataset to perform a smart agricultural system. For that intention, we created target-based research questions.

- How will the agricultural sector get benefited from using emerging technologies such as IoT and data analytics?

- How different IoT and data analytics solutions prove themselves to be best?

- How to develop the most reliable, efficient, flexible, and cost-effective systems that meets current agricultural needs?

- What implications these findings have?

- What kinds of data are needed to achieve a smart agricultural system?

- How to design proposed smart-agriculture architecture?

- How can IoT and data analytics be applied inside a smart agricultural system?

- To know the research gap and research agendas to contribute further research.

\section{METHODOLOGY USED :}

The proposed study uses the method of data and information collecting to study the literature on said topic. All the data and details that were collected are accessible online using secondary data, research papers, books, journals, and magazines. In addition, here first all the research materials were collected and then the analysis process was done and the common issues were identified in the whole paper, then our own theory was established. The tool used here is the qualitative approach where attitude, perception, and behavior are correlated with the study. The result obtained is also in non-quantitative form. So, the focus of the work is on our insight into science and depth. Afterward, we built our own architecture based on the knowledge learned after the review process from the reviewed paper.

\section{RELATED WORK ON SMART AGRICULTURE :}

Sawaitul et al. (2012) [9] identify an appropriate solution for climate predicting by introducing a new wireless equipment, which includes a back propagation algorithm. This algorithm is applied to weather forecasting dataset and observed the variation on other factors with respect to the change on one factor. Neural networks are proficient of molding a weather prediction system. The neural network signal dispensation method for weather predicting is capable of generating good yield results and can be reflected as substitute to old climatological approaches. Jagyasi et al. (2013) [10] presents different ICT and mobile sensing technologies that enhance the efficiency of agriculture and enable us to connect farmers with concerned entities in the ecosystem. mKRISHITM is a technology outline for mobile based agro-advisory facilities, which connect the countryside community with agricultural specialists through cell phones and sensor networks. In agriculture, a microphone as a mobile sensor can be used for sensing pest existence in the field. These pests are identified by examining the sound they make, by using signal control, guesstimate and recognition algorithms. This supports farmers take required measures to diminish harms due to pest attacks. Li et al. (2013) [11] address the problem by developing a platform for data analysis of machinery used in agriculture. This research is focused on machinery used in agriculture, such as tractors, cultivators, harvester and dryers. In the beginning, this application collects data regarding machinery conditions, than using big data platform it analyses machinery conditions using various indicators, then sends warning messages by prompting maintenance needs. The data inspection inter system in this study is parallel to the data process platform, is the system application that executes the data analytical techniques and display the results as analytical consequences. In this study, the MapReduce data analysis engine established on Hadoop technology and the Spark engine well-matched with Hadoop technology are generally used. Kang et al. (2013) [12] explains weather data analytics which remotely collects the weather information and stores it in a cloud database accessible from any location. The proposed new method of efficiently collecting data led to new wireless sensor network applications. The concept is to use real-time sensors installed in the field of a subject so that data can be collected in a real environment and made available for future machine learning.

Mahmood et al. (2013) [13] elaborates on the characteristics of different BDA tools. The different characteristics such as cloud integration, scalability, query based, parallel processing features, handling arranged and dispersed data, freeware and Hadoop integration feature of multiple big data apparatus 
such as Hadoop and MapReduce, IBM big data analytics, Kognito WX2, SAP big data analytics, Microsoft Big data-Azure, Oracle big data analytics, Tera data big data analytics, SAS big data analytics were discussed. Yang et al. (2013) [14] provides IOT enabled smart farming solution using data compression and cleaning methods as well as decision-knowledge procedures. In the proposed system the moisture data, temperature data are acquired from sensors ZigBee network. Kalman filtering reduces noise in sensed data and performs compression. The IoT postern and cube connected on RaspberryPi transfer the data. IoT service platform Mobius makes virtual data storage on sensed data. The decision tree algorithm performs a forecast about crop development by means of decision learning. Here, the decision is conversed to the user by mobile or web browser.

Jeong et al. (2014) [15] identify the solicitations and procedures of data mining in farming. It addresses the problem of price prediction for agricultural crops. The categorization and grouping methods are two forms of data mining techniques. For this, it can able to find appropriate approaches of data mining like K-Means, K-Nearest Neighbor and artificial neural networks. Neural Networks and Support Vector Machines are two categorization methods that are used commonly to categorize unidentified sample. Here, clustering methods enables to raven a set of unknown samples into clusters. K-Means technique is well known and frequently used clustering techniques. Data mining categorization approach can be used to improve a pioneering form to forecast the market value of the particular goods. Medar, R. A., \& Rajpurohit (2014) [16] explains different data mining approaches in agriculture to develop the forecast models. The K-Means, K-Nearest Neighbor (KNN), Artificial Neural Networks (ANN) and Support Vector Machines (SVM) are data mining approaches preliminarily used in the forecast model. The regression method is the conjoint method for forecasting yield through a bulky area. Generally, Neural Networks and Support Vector Machines, these two categorization approaches that studied about categorization of unknown samples. Another classification technique, K- Nearest Neighbor, does not have any knowledge part because it practices the training set every time a grouping must be performed. If there is no earlier information about the data to classify than the clustering methods will be used. KMeans algorithm is most frequently used clustering algorithm.

Parthasarathy (2015) [17] proposed the application that forecasts the environmental changes using a big data approach which improves productivity. It presents an improved forecasting technique works automatically based on the Hadoop framework for analysis and forecast. The MapReduce in practice of Hadoop to monitor and analyze the big data composed from various foundations like weather forecasting, sensor data, market tendencies and social media data. Application has 5 modules for data acquisition, data storage, query analysis and presentation. Application projects the climatological data storage as well as processing policy grounded on Hadoop framework with the help of linked logistic reversion procedure for forecast. Sankaralingam et al. (2015) [18] introduced a crop simulation model based on site specific daily weather data, soil and crop data. It is used to appraise crop vintages by variations that happen in crop physiognomies. With the aid of FieldScout and GreenIndex farmers able to find depiction of their crop, and the application calculates nitrogen solicitation rate commendations constructed on a colour index, this offers planters with a low-cost technique for dealing in-season fruitfulness which can progress yields, inferior nitrogen expenses, and upsurge earnings. Yadav et al. (2015) [19] presents the big data that bump into small-scale sensors in precision agriculture. It gives solutions for the big data e-agriculture service includes the prevalent current technologies such as HDFS, Map Reduce, Hadoop, STORM, etc. Also, they analysed that the Big Data in agriculture refers to the Electronic Farm Records (EFR) which includes data on soil, temperature, precipitation, electrical, moisture, air, nutrient and PH levels. Several sensors can be used in real-time or in permutation with a Global Positioning System (GPS) to create field maps of different soil properties. He concludes that the sensing of soil and crops has turned the agricultural system into much more productive, less costly, and better quality than ever. The spread of intelligent sensors with efficient analyses of big data will lead us a pace on the way to freeing farmers from the restraints of unpredictable weather conditions. Forkan et al. (2015) [20] proposed the IoT system used to senses data related to agriculture and is stored in the remote database. The data wizard is analysed using cloud-based big data processing. Here specifications for fertilizers, crop research, demand specifications for the crop. The prediction is then conducted using a data mining approach in which knowledge enters the farmer via a cell phone device. Using this predicted knowledge, our goal is to upsurge crop manufacture and governor the agricultural costs of the goods. Li et al. (2015) [21] give the latest prominent context-conscious middleware solutions during the period from 2009 to 2015. The IoT-based context explains awareness framework and its middleware 
architecture and different context-consciousness levels. Channel et al. (2015) [22] explain a multidisciplinary model for intelligent farming using IoT, Sensor, web Computing, Mobile Computing and Big Data Analysis has been suggested. Farmers, Agro-Marketing companies, and Agro-Dealers must be registered with the mobile application in the Agro Cloud network. Agro Cloud disk is used to hold farmers' data, periodic farmland soil resources, agribusiness and agri-marketing companies, agrie-governance arrangements and present ecological conditions. Properties of soil and atmosphere are sensed and occasionally transmitted to Agro Cloud via IoT (Beagle Black Bone). Agriculture cloud data is conducted for the need of fertilizers, yield analysis, production summary, and present store and market demands. The proposed model is helpful for cumulative agro-product progress and cost control. Sravanthi et al. (2015) [23] suggest biotechnology companies test crops and perform simulations to assess how different plants react to altered circumstances. They provide a thorough overview of Big Data's position in various areas of agriculture. Vicissitudes in the qualities of the different data it pleats, including temperature, water echelons, soil configuration, growth, production, and gene sequencing of each plant in the testbed. These imitations allow it to determine the ideal situations for specific types of genes.

Ramesh, D., \& Vardhan, B. V. (2015) [24] offerings a transitory analysis of crop forecast by means of the multiple linear regression (MLR) method and Density-based clustering method for the particular province. The foremost intention of this paper is to establish user approachable design for farmers that provide the analysis of rice production grounded on existing data. Primarily, the numerical model multiple line regression technique is pragmatic to present data. The consequences so gained were data mining technique specifically the density-based clustering technique. This yield forecast model is reachable with the exercise of the multiple linear regression (MLR) technique where the forecast is the production and it has seven prognosticators namely year, precipitation, expanse of spreading, crop and nourishments (Nitrogen, Phosphorous and Potassium). Area-explicit crop yield analysis is achieved by realizing both the Multiple Linear Regression technique and Density-based clustering technique.

Ravisankar et al (2016) [25] reviewed B\&M data (big data and metadata) supervision related research in contemporary biosphere situations. Also presents design for U-Agriculture Mobile Services grounded on Sensor-Cloud Setup. It initiates that both big data and metadata play vital protagonists in omnipresent agriculture in handling the progressively multifaceted amount of data that are being connected with applications or services or systems. The capability of hardware sellers that afford outfits, facilities and podiums for dealing big. Also Microsoft is proposing mobile amenities using azure app services. Azure App Service is a novel and exclusive cloud service that empowers developers to generate web and mobile apps for any dais and any expedient. Stubb, M. (2016) [26] investigates how data has been generated and collected by the farmer and other sources using current and innovative technology present today. Normally, data gathering comprises somatic technology, such as sensors, imagery, drones, radar, and other technologies all functioning together to deliver comprehensive evidence about earth content, tidies and vermin, daylight and gloom, nutrient shortages, humidity, and other issues. The other portion is the network through which the technology transfers, normally the Internet. This is commonly mentioned to as the "Internet of Things" (IoT) - networks of things that interconnect with other objects and with computers over and done with the Internet. Ingale et al. (2016) [27] suggested a large amount of data set will improve the analysis and predictive decision making power of actors related to the agriculture sector. An agriculturist could take a photograph of a yield with his smartphone and exchange it to a database where authority could assess the advancement of the item in light of its shading and distinctive properties. Ribarics, P. (2016) [28] looks at the role big data plays in agriculture. Big Data may form the basis for several new capabilities, including the identification of associations between field, weather and commodity data for optimum irrigation, reproduction, optimum livestock feeding and marketing. Prognostic analytics can be used to predict seed demand, nourishments, and animal feedstuff and allow the supplier of agri-business to receipts appropriate actions to meet claim progress. New pricing systems may be set up to help balance the market in line with the supply available. $\mathrm{He}$ concludes that big data analytics is one of the solutions for sustainable farming and minimizing its footprint. Carbonell, I. M. (2016) [29] presents predictive farming suggested using current data from the sensors, historical data available in databases, and future events. It helps farming companies to predict customer land requirements based on data and use data analytics. It explains how business people collect data from farmers from an ethical point of view for predictive analysis and effect on the confidentiality and safety of farmer's data. Nandyala, C. S., \& Kim, H. K. (2016) [30] recommend the 
type of sensor methods, technologies, implementations and benefits of numerous kinds of sensors for mobile services to be used in their decision making. To end with, it presents U-Agriculture Mobile Services design centred on Sensor Cloud Infrastructure that not only benefits plantations and solicitations, but service suppliers and societies also manage B\&M data.

N. Nalini et al. (2017) [8] explains Data Analytics, Stuff Internet, and Health Care Studies. Upgrades in agriculture through the use of the Internet of Things and sensor data analytics gathered field level information. The application proposed here performs three main things. One is a compilation of information, the second is identifying unknown occurrences and the third is applying results to the application concerned. The data are from the sensors for agriculture analytics. These findings help us predict the plants of the future and contribute to bearable agriculture. His proposed application for AgriIoT includes 6 main layers, as shown in figure 1.

\begin{tabular}{|l|}
\hline End Operator \\
\hline Solicitation \\
\hline Tunneling of data \\
\hline Data gathering and scrubbing procedure \\
\hline Communication rules \\
\hline Hardware device \\
\hline
\end{tabular}

Fig. 1: Layers in Agri-IoT application

First, we chose the correct hardware to add to the problem statements to build Agri-IoT Product. Then, there will be the data collection and cleaning process involved. Must be mined on the actually collected data information and the application will extant the extracted results to end-users. The Agri-IoT can be applied to seed collection, field mechanization, precision and accuracy planting, soil erosion, promotion of agriculture and irrigation systems. This application's problem is spatial imbalance and temporal imbalance. The application's analytical section varies according to the area. The application's analytics part produces the data, and we make the decision based on the report. So it should produce the report within a short time. Kamilaris et al. (2017) [31] presents smart farms with the objective of developing information technology in e-commerce and addressing the problem of farms including growing yields, water conservation and soil and plant health, and promoting new sustainable agricultural science. With a new open-source, IT framework named UCSB Smart farm, he achieved that goal. The smart farm is a hybrid cloud platform designed to allow smallholder farmers and other farm professionals, researchers and students to use analytics to improve environmental sustainability and food production efficiencies. Nayyar, A., \& Puri, V. (2017) [32] proposed IoT Smart Stick that will allow agriculturalists to have data on live soil humidity, atmosphere temperature at a very little price tag, so live checking can be prepared. Adequate water is essential for carrying out agricultural activities in an efficient manner. Agriculture IoT is combined with Web Map Service (WMS) and Sensor Observation Service (SOS) to guarantee appropriate irrigation water controlling and diminish water surplus in effect. Agriculture Temperature and Moisture Control Smart IoT Based Agriculture Stick is being proposed. Nuvvula et al. (2017) [33] introduced a system designed using Arduino expansion kit which links to light sensor gauging the light intensity, atmosphere temperature/moisture sensor for receiving the humidity in the environments, soil moistness sensor for measuring level of water, and air poisonousness measuring carbon dioxide and oxygen stages. Device has been explicitly premeditated to analyze the atmosphere and report to the agriculturalist, round-the-clock, via the Wi-Fi connectivity incorporated into it.

Marjani et al. (2017) [34] analyzed the connection between big data analytics and IoT. It proposes architecture for big IoT data analytics and technologies for data mining. Instantaneous analytics is characteristically achieved on data composed from sensors. Rapid data analytics techniques must achieve an analytical consequence within a tiny period. It presents big data analytics approaches under 
organization, bunching, connotation rule mining, and prediction categories. In smart agriculture, text and image data are captured from IoT devices, and Hadoop application is used for big data analytics. Maksimović et al. (2017) [35] adopt the application of green nanomaterial in recent farming to decline the practices of injurious and expensive nourishments. Thus, the solicitation of nanotechnologies and IoT in this area can seriously explore the difficult of sustained farming. It exemplifies a learning of Green-IoT and Green nanotechnology's part in understanding smart and supportable agriculture. Bhavani et al. (2017) [36] reviewed tools and applications that support the execution of big data applications for agriculture exercise. The comprehensive building of Hadoop Ecosystem and its mechanisms has been scheduled along with their context. These apparatuses are used to forecast upcoming analysis by using the calm Dataset. Rajeswari et al. (2017) [37] reviewed the assimilation of various big data analytic techniques and implementation of it in various agricultural fields. The challenges of big data analytics are discussed here. Different data analysis techniques such as prognostic analytics, reference system, and data mining, time series analytic technique are applied to a different area of agriculture. Gill et al. (2017) [38] Refers the Electronic Farm Record (EFR) which contains earth temperatures plots and evidence, rainfall maps and information, electrical conductivity maps and material, mugginess gratified statistics, air permeability maps, $\mathrm{pH}$ level statistics, historical progress proceedings, security and crop connected data and online post comprising chirps, websites, new withstands and articles in agribusiness diary.

Al-Kahtani, M. S. and L. Karim (2018) [39] presents the dynamic data processing method for big data sensors. It suggested how to reduce energy consumption using a multi-tier architectural system, and how to perform data aggregation in each layer to reduce the IoT device's energy consumption. Parent nodes accumulate data as they are communicated at the origin of the tree on the way to the sink. The network structure is primarily established on an in-link approach to data aggregation. When an event is observed by a sensor, if the data is gained from a fixed sensor application the sensor implements an innetwork data combination scheme. When data comes from a mobile sensor device, a grid-based method is used to integrate the data.

\begin{tabular}{|l|}
\hline Layer 3 data aggregation (Response center- \\
SQL server) \\
\hline $\begin{array}{l}\text { Layer } 2 \text { data aggregation (Base station - } \\
\text { Internet) }\end{array}$ \\
\hline Layer 1 data aggregation (Sensor network) \\
\hline
\end{tabular}

Fig. 2: Big data aggregation center

The proposed Big Data accumulation and cleaning architecture works in three covers, as seen in Figure 2. The lower layer aggregates sensor data. The central layer group's data at the base station and the upper layer totals data in a dispersed mode on the big data server. The lower layer of this model contains sensors that need to be configured in such a way that every event happens, matches the data with the field value and then transfers it to the middle layer. More data aggregation occurs at the middle layer and the top layer of the model receives partly organized data. This way reduces the difficulty of the top layer data analysis. They conclude in this application that if the distance between the nodes (sensors or devices) is lower than the energy consumption is lower, too. The sensor transmits the data from itself to the sensor gateway in the shortest possible way. Wolfert et al. (2018) [40] presented a paper on Big Data for Smart Agriculture. They find that the rapid Internet of Things and web computing growth propels the indication of smart farming. This model summarizes the concept of smart farming as a cyber-physical system along the management cycle, which points to intellectual expedients-associated to the web-control the farm system. Smart devices encompass traditional resources (e.g., flood measure, tractor, and notepad) by incorporating independent situation-consciousness through all sorts of sensors, built-in cleverness, capable of performing or doing something the slightest bit, independent activities. In this context, the business practices (lower layer) concentrate on the generation and utilization of big data in agricultural process. This part is divided into the chain of data, and farm supervision and agricultural processes. The data shackle cooperates with farm procedures and farm organization 
procedures over and done with many processes of assessment making, in which facts theaters a significant character. The link of investors (middle layer) includes all investors intricate in these procedures, not just big data consumers but also corporations specializing in data processing and controlling and program actors. The web management (upper layer) technology component focuses on information set-up, which supports the chain of data. He concludes that sensor implementation and analytics, prognostic modeling, and the use of improved models to handle yield failure danger and improve feedstuff performance in livestock production are opportunities for big data applications in food production. Big data are intended to deliver prognostic visions into upcoming agricultural likely results (prognostic harvest model, prognostic nourish consumption model, etc.), drive operational decisions in real time and reinvent corporate developments for faster, advanced action and changing corporate models.

Liu et al.(2018) [41] propose an idea to syndicate smart agriculture and clean energy consumption by using surplus clean energy in agriculture production. It uses smart agriculture to provision power system with clean energy consumption. Here, smart farming and clean energy systems combine to meet power demand. The bottleneck technologies for smart agriculture and clean energy systems are multiline scale coupling, measurement and monitoring system, multisystem correlation-coupling system, economic evaluation system and model of smart agriculture load. Aliev et al. (2018) [42] Presents a real-world method to attain data on heat, moisture and soil moisture of plant life. It develops a model device and android application to get bodily data and directs it to the cloud. Also presents the use of an ANN as a time series predictor to forecast the temperature. They realize this over industrialized IoP device and Android platform, which delivers the data, attained from the farming atmosphere to the web over the Thing-speak platform. The Thing-Speak-IoT platform offers applications that contract you analyze and posturize your data in MATLAB platform. Data from sensors can be transmitted to Thing-Speak from other hardware. Jerzak et al. (2018) [43] examine the impending for a new Information and Communication Technologies-led model of progression and expansion in the agronomic sector in India. The project's objective is too improved realize the role of ICTs in India's future monetary development and to make references for India to carry on to leapfrog the progress process using ICTs in key segments including agriculture, among others. Ngo et al. (2018) [44] designed the system and database scheme to implement continental level data warehouse that supports big data analytics and storage. It built an efficient system to handle agriculture and practical data mining techniques. This model mainly contains a raw data module, abstraction renovation module, incorporated information module and data mining module. The data are usually extracted in the practice of a data cube beforehand it is analyzed in the data mining segment. A data cube is a data building that permits reckless analysis of data conferring to the numerous extents that outline a commercial problem. The data cubes are created by an online analytical processing engine (OLAP). Aher et al. (2018) [45] propose fog-centric power effective design for a smart agriculture system. Here the fog bulges are placed very close to land and real-time data manipulations is processed in the fog layer, which lowers the work load in the cloud layer. Here the fog layer collects data from agriculture IoT sensor layer and performs real-time processing in which farmer gets a faster response. Cloud Layer handles the agriculture data received from the fog layer for storage and processing using data centers located on the cloud. CobleKaur et al. (2018) [46] suggested the complex world of the technological era, there is a unique and kind role for data analytics and applied economics. Applied economics is equipped with unstructured data, and very relaxed. Agriculture and applied economics read the next generation with geospatial analytical preparation and techniques. Kovács, I., \& Host, I. (2018) [47], suggested document 4.0 on the part of digitization in agriculture. This paper systematizes the art of smart farming, the IoT, cloud computing and big data. Geo-location tools such as GPS, GIS, crop tracing, precision earth sampling, proximal and distant recognising, without human in-flight vehicles, auto-managed and guided apparatus, and flexible rate equipment allow field-based operations. Animal-attentive technologies include RFID chips and automated milking and feeding systems, among others. The StarFire 3000 receiver collects satellite broadcasting signals from the GPS and can use GLONASS satellites to preserve supervision recital even under sheltered circumstances and other changeable situations. Thus, the receiver should compensate in the field to ensure true vehicle location regarding the ground. Finally, he concludes that smart farming uses technology, sensors and big data from GPS systems, device to device (M2M) and the Internet of Things to maximize crop yields and minimize waste. Kumar, H., \& Menakadevi, T. (2018) [48], published a review paper on data analytics in the agricultural sector. This paper discusses Big Data applications to 
support agriculture and methods to help the execution of Big Data applications for agricultural facilities. He noted that all data collected were mapped to the organization system using a topographical information system and advanced sensor apparatus, which will improve the crop's sustainable productivity with greater benefit. This paper also includes the implementation of the Apache Hadoop framework and the core elements thereof. Ultimately, he concludes that precision farming provides farmers with technological backup support for applying technology in agriculture. In addition, it also found that Hadoop is the best platform for processing massive data sets in agriculture. B. Santhiya et al. (2018) [49] suggests using the LPC2418 microcontroller to direct and obtain data from the webbased network using web-enabled applications. It had QOS including good response time, productivity and availability that would be ideally suited for monitoring and managing townhouse gardens from remote locations.

Sarker et al. (2019) [50] focuses on the suitability of big data technologies in the agriculture sector. The big data based digital agricultural technology can help farmers from the field preparation to harvesting, such as weather forecasting, crop yield prediction, yield collection, irrigation supervision, crop viruses and pest supervision, agricultural selling and agricultural pest management. Jain, A., \& Kumar, A. (2019) [51] Presents a model that collects temperature data and water level data from various sensors and displays it in an LCD screen. Then, these data are given to microcontroller, which analyses it and transmits it to the server using Wi-Fi connection. The server performs the data analytics on data and generates the result in the form of output. Mathivanan, S., \& Jayagopal, P. (2019) [52] provides a complete evaluation of big data virtualization in the agriculture purview. The big data virtualization enables farmers to take well decision-making tools such as SQL virtualization for integrated access, query, reportage, prognostic analytics, back-end data warehouse, such as Hadoop, and NoSQL. Due to the accumulative complexity of big data, we need data virtualization, and its arrangement. Surya, P., \& Laurence Aroquiaraj, I. (2019) [53], proposed an overview of efficiency of K-means and K-medoid clustering algorithms using data set on agriculture. Data mining is a method of mining information from a massive sized data set, where clustering is used to identify related items within the dataset. The main goal of this paper is to find the best clustering technique in the Agriculture dataset for classifying a similar group of objects. In an article he used the clustering technique for evaluating the report on agriculture. He applied clustering techniques for K-means and K-medoid to the Agriculture database. Cluster is a data object array and clustering is the technique for partitioning or segmenting the data into classes. The most associated data are grouped into the cluster. The accuracy, precision, and recall in the case of the k-means algorithm are poor after the experimental analysis, and it is high in the case of kmedoid. The mean square error and square root mean error are high in k-means, and small in k-medoid. Results exhibits the k-medoid clustering algorithm has great precision and a lesser error rate compared to the k-means clustering algorithm. By these findings, k-medoids gave this Agriculture dataset a better output. Anushree et al. (2019) [54] proposed an article on the evaluation of a network of wireless sensors in precision agriculture. This paper consists of a survey on wireless sensor networks on Precision agriculture, with different web-based IOT systems. A web-based IoT architecture is used that consists of three layers. The front-end layer applies the requisite agricultural activities that are collected as information about the environment. The gateway layer links the front-end layer to the internet and the entire process that is occurring, and the data storage in the back-end layer has happened. He clarified the design of WSN and of WSN nodes. He concludes that many agricultural production systems will increase the efficiency, productivity and profitability of precision agriculture by using Wireless Sensor Networks (WSNs). Liu et al. (2019) [55] proposed a solution for agricultural issues using modern technologies IoT and big data solutions. It uses lot of vulnerable source application and open library documents. For access hardware, it uses ports, RPI.GPIO and WiringPi. PySerial is used for UART ports. Video scrutiny is useful and constructed on motion. Paho-python is used for communication broadcast and analysis, web service is made with WebIOPi. Other components delivered by Python are also functional. Through video reconnaissance, operators identify the development of land activity remotely and in real-time and monitor the actual process rank of the Internet of Things device. One of the basic purposes of the model is to deliver instantaneous data requests and information. For that, it uses Hadoop service EMR (Elastic MapReduce) by Amazon. Through this, it is possible to rapidly conduct analysis through machine learning, confirm the expectation of demonstrating, and then use the system to forecast on a huge gauge. Jboss is chosen as the development server of the system, which is openly available and with free of cost, and has a less source employment, and wires highest level of 
concurrency. The client side of web server is Nginx to distinct the static and dynamic resources. Chen, J., \& Yang, A. (2019) [56] makes a smart agricultural system is made using IoT, data imagining analysis and constellation analysis. Agricultural activities are promoted by detecting, identification, broadcast, checking and feedback of IoT. The collection of agricultural data has done by IoT and data analyses were performed by visual interactive system. IoT mainly has four core technologies that are sensor equipment, RFID equipment, and rapid response code and embedded system technology. The visualization technology is used to collect data, which is transferred to the cloud where cluster processing was achieved and placed in the data source. Then, the information is transferred to the user terminal in the form of a graph. The spring framework is used for data visualization, which contains a web browser, web server and SQL database. The main responsibility of a web browser is to interact, parse, map and display modules. Web server interacts with user requests, querying databases and, fetches relevant data from the database. SQL database is used to store relevant data. Kamath et al. (2019) [57] analyze the execution of a wire free chromatic sensor network for accuracy farming. In sensor nodes, Bluetooth 4.0 directs data for the base station. Bottom station forwards data to the distant station using IEEE $802.11 \mathrm{a} / \mathrm{b} / \mathrm{g} / \mathrm{h}$ standard. Planetary cubicle battery used as the control source at both base station and sensor nodes. By using support vector machine classifiers different shape features were extracted at the remote station. The bottom station receives the images and stores them in the line maintained by RabbitMQ. Plant objects from images developed by Raspberry Pi. A agent that performs a random forest classifier, and evaluation type of classification. From this application, we observed that a wireless ocular sensor network could be established for checking crops for pests using Raspberry Pi. The extended this network by using different sensors such as earth humidity sensors, optical sensors, moisture sensors, and temperature sensors that a low-cost, full-fledged yield-checking model is developed. Hu et al. (2019) [58], introduced relay-aided Non-Orthogonal Multiple Access (NOMA) for uplink transmission in WSNs to achieve smart and intelligent agriculture. This NOMA technique can lodge extra sensor nodes with the same Relay Equipment's (RE).NOMA can transmit several symbols at the same time on the same Relay Equipment's (RE's) by excruciating them with power field and discriminate them with different power levels. The next generation communication technology 5G, NOMA achieved a high data transfer rate and huge uplink and downlink transmissions. Tseng et al. (2019) [59] introduced an intelligent agriculture platform using IoT and data analysis to monitor environmental factor and yield analysis using 3D cluster analysis. In this scheme, data normalization is attained using a mixture of much average variance. The 3D analysis is used to analyze the environmental factor. The System arrangements the vital value in the selected group based on the prospect environment and offers guidance to the former whether the crop is appropriate to farm. This intelligent agriculture has futures such as IoT sensors, solar storage system and web platforms that help assemble evidence from IoT sensors. Big data analysis approach includes data normalization using average variance, 3D analysis to analyze the connection between different ecological factors, to determine whether the selected crop belongs in the suitable group, and setting significant value in the group for giving advice on former about the crop cultivated. Farooq et al.(2019) [60] presented core technologies of smart farming that was network technology used in IoT, cloud computing, big data storage and analytics. The 4 major mechanisms are the physical construction, data gaining, data dispensation, and data analytics. The physical structure is designed and it controls devices. Data acquirement is further divided into IoT data acquirement and normal data acquirement. Data processing includes picture and video dispensation, data loading, decision carry system, and data mining. Finally, data analytics has 2 main features include monitoring and controlling. It also analyzed the different communication protocols of network technology, including WiFi, Lora Wan and code division multiple access (CDMA) technology. ZigBee network is the main Internet technology used for long distance. Tóth, M., Felföldi, J., \& Szilágyi, R. (2019) [61] explains how IoT technology was analysed and tested with sensor technology and wireless network integration system. Remote Monitoring System (RMS) is proposed to incorporate an approach with web and wireless communications. The key aim is to gather timely agrarian production atmosphere data that enable easy admittance to agricultural amenities such as warnings via the SMS and weather conditions, crops. Rao et al. (2019) [62] study large-scale farming using IoT and data analytics. Here he overcomes the issue of rising power consumption in IoT devices through the implementation of a centralized sensor control unit. A centralized platform is deployed with a Zigbeeconnected wireless sensor network. He argues that Zigbee has greater wireless connectivity than Wi-Fi connectivity. 
Rasooli et al. (2020) [63] suggested the development of a system called the optimal watering of crops based on a WSN. This research was designed at scheming and evolving a system that uses harvest ground node sensors with data supervision over mobile and an online application. The three elements are the Software, Internet, and Phone. Pini et al. (2020) [64] presented a trial setup and practice to test the performance of RTK-GNSS based devices in the functional demonstration. Also, extracts the limits of GNSS in precision agriculture based on small robots and AI. The analysis confirms that RTK provides the best performance and maximum level of location accuracy and exactness for agricultural talks. The RTKGNSS based device matches a performance requirement which is used for machinery direction and involuntary field management using a wireless network connection. Saad, A., \& Gamatié, A. (2020) [65] presents recent works on management of water and agricultural work miniaturization system by using advanced technologies. By simplifying water management practice by using appropriate computerization level and provides agriculturist to connect to the system at any time anywhere basis. The sensors are installed in WSN and CPS setup and it produce enormous data stored and handled in a large scale. CPS is an assembly of wireless sensor device with low-level calculating, storage of data and message abilities. The system alienated into multiple layers cooperating with unswervingly by using a wireless network frontend and backend. The foremost layer consists of IoT devices and the next layer contains of storage of data and servers itself makes cloud environment. APIs can be delivered to recover data in the web platform or expansion of mobile applications. Gupta et al. (2020) [66] provide a summary of smart agriculture focused on multilayered structure. The proposed architecture exposes IoT and Cyber Physical System (CPS) multilayer architecture. The cloud and edge services are capable of storing and process large amount of data generated by physical devices. It also considers, massive amounts of data composed at the edge or cloud layers, and climaxes the need for numerous multi-cloud or edge-cloud scenarios. The distinctive construction contains mainly 4 layers such as corporal layer, edge layer, fog layer and network message layer. Liu et al. (2020) [67] proposed an exactness directive model of ACPS. This model interacts with the environment to improve water and fertilizer regulations. It verifies and analyzes PRMWFA-ACPS by relating the replicated and dignified values of development period, leaf characteristic, and soil moisture content. This model built an inclusive biophysical model into ACPS, which comprises construction of a biophysical model in ACPS that interrelates with the communication model, constructing a model of water and fertilizer for alfalfa based in ACPS (PRMWFA-ACPS). The PRMWFA-ACPS mainly comprises 3 gears such as physical atmosphere, calculation situation and cyber-physical communication. The physical atmosphere involves of environment conditions such as temperature, solar radiation and basic ecological limitations. The computation atmosphere is composed of calculation entities, which are accuracy rule approaches. Gulec, O., Haytaoglu, E., \& Tokat, S. (2020) [68] introduced a newly distributed CDS algorithm namely CDSSEHA, in WSN, solar energy harvester node, especially for accuracy agriculture application. The various types of corporal, substance and natural features of agriculture are deliberate and used in smart agricultural applications. Here application uses mobile sensors that move randomly on the farm and gathers the data. These data were analyzed in base station to protect against bacterial and fungal disease through an image processing technique. The communication backbone was constructed between node and base station was achieved using CDSSEHA. The performance of the proposed application is achieved through the said algorithm through the network. Huang et al. (2020) [69] Introduce a new concept called PAIoT. This system uses renewable power in agriculture that was controlled by the IOT device. The multimedia data stream of disease and creature pests, crop progress, broadcast and soil moistness and procedure status of the photovoltaic module is gained during the process. The photovoltaic panel is complete use of water property, node installation and optimization of expenditure for sensor networks through multiple functions. Optimize image transmission and power generation on the environmental climate. The optimization of image data transmission can be achieved using 3 methods such as communication quality, image quality, storage and computational capability. Computational capability can be achieved by edge computing, cloud computing, and fog computing that supports big data processes. 


\section{QUALITATIVE ANALYSIS ON SMART AGRICULTURE SYSTEM :}

IoT and data analytics are two key technologies that are used in smart farming. The success and failure of smart farming systems are largely dependent on implementing these 2 technologies. Both IoT and data analytics can be used differently and a suitable and adequate method for smart farming needs to be determined. This segment discusses some of the discussed methods in the literature. Table 1 offers a comprehensive overview of Smart Agricultural System methods. Table 1 below narrates the name of the speaker, key features, methods, and benefits of the application proposed.

Table 1: The comparative analysis of smart agricultural system.

\begin{tabular}{|c|c|c|c|}
\hline Authors & Features & Approaches/Techniques & Benefits \\
\hline $\begin{array}{l}\text { Sawaitul et al. } \\
\text { (2012) [9] }\end{array}$ & $\begin{array}{l}\text { Wireless } \\
\text { Sensor } \\
\text { Network and } \\
\text { data mining }\end{array}$ & $\begin{array}{l}\text { Back Propagation Algorithm, } \\
\text { Artificial Neural Network, } \\
\text { Classification and Prediction } \\
\text { Techniques. }\end{array}$ & $\begin{array}{l}\text { The system upsurges the } \\
\text { consistency, accurateness and } \\
\text { steadiness of identification and } \\
\text { understanding of weather } \\
\text { images. }\end{array}$ \\
\hline $\begin{array}{l}\text { Jagyasi et al. } \\
(2013) \text { [10] }\end{array}$ & $\begin{array}{l}\text { Wireless } \\
\text { sensor network }\end{array}$ & Mobile sensing technology & $\begin{array}{l}\text { It is low-cost, robust, care free } \\
\text { and effortlessly deployable on } \\
\text { the plantation, helps the } \\
\text { agriculturalists by distributing } \\
\text { the right information } \\
\text { inappropriate way connected to } \\
\text { crop planning, water supervision, } \\
\text { pest/disease management, market } \\
\text { relation, etc. }\end{array}$ \\
\hline $\begin{array}{l}\text { Li et al. (2013) } \\
\text { [11] }\end{array}$ & $\begin{array}{l}\text { Big data and } \\
\text { data analysis }\end{array}$ & $\begin{array}{l}\text { Data filtering, Data fusion, } \\
\text { Time series, Anomaly } \\
\text { detection }\end{array}$ & $\begin{array}{l}\text { Nominal relationship of } \\
\text { agriculture machinery component } \\
\text { is surpassed } 80 \% \text {. }\end{array}$ \\
\hline $\begin{array}{l}\text { Kang. et al } \\
\text { (2013). [12] }\end{array}$ & $\begin{array}{l}\text { Data analytics } \\
\text { and WSN }\end{array}$ & $\begin{array}{l}\text { Real time data collection and } \\
\text { used in future for machine } \\
\text { learning. }\end{array}$ & $\begin{array}{l}\text { Weather station connected to } \\
\text { WiFi and can find temperature } \\
\text { and humidity at any spot. }\end{array}$ \\
\hline $\begin{array}{l}\text { Mahmood et } \\
\text { al. (2013) [13] }\end{array}$ & $\begin{array}{l}\text { Big Data } \\
\text { Analytics }\end{array}$ & online analytic processing & $\begin{array}{l}\text { Makes machine, industry, cities, } \\
\text { business smart by using online } \\
\text { tools and component. }\end{array}$ \\
\hline $\begin{array}{l}\text { Yang et al. } \\
(2013)[14]\end{array}$ & $\begin{array}{l}\text { Wireless } \\
\text { sensor } \\
\text { networks, } \\
\text { Internet of } \\
\text { things }\end{array}$ & $\begin{array}{l}\text { Kalman filter, data } \\
\text { compression and filtering } \\
\text { techniques }\end{array}$ & $\begin{array}{l}\text { Automated solution for data } \\
\text { acquisition, provide low-cost } \\
\text { communication, decision support } \\
\text { system for irrigation, } \\
\text { nourishment and insecticide } \\
\text { levels, likely upcoming } \\
\text { infections. }\end{array}$ \\
\hline $\begin{array}{l}\text { Jeong et al. } \\
(2014)[15]\end{array}$ & Data Mining & $\begin{array}{l}\text { K-Means, K-Nearest } \\
\text { Neighbor, Artificial Neural } \\
\text { Networks, Support Vector } \\
\text { Machines, Classification and } \\
\text { Clustering Techniques }\end{array}$ & $\begin{array}{l}\text { Groundbreaking model to } \\
\text { forecast the marketplace price of } \\
\text { the particular product. }\end{array}$ \\
\hline $\begin{array}{l}\text { Medar, R. A., } \\
\& \quad \text { Rajpurohit } \\
(2014)[16]\end{array}$ & Data Mining & $\begin{array}{l}\text { K-Means algorithm, K } \\
\text { Nearest Neighbor (KNN), K- } \\
\text { Means approach }\end{array}$ & $\begin{array}{l}\text { Different potential fluctuations } \\
\text { of the climate situations are } \\
\text { analyzed using SVMs, K-Means } \\
\text { method is used for categorizing } \\
\text { soils in mixture with GPS-based } \\
\text { technologies. }\end{array}$ \\
\hline $\begin{array}{l}\text { Parthasarathy. } \\
\text { (2015) [17] }\end{array}$ & $\begin{array}{ll}\text { Big } & \text { data } \\
\text { analytics } & \end{array}$ & $\begin{array}{l}\text { automated prediction } \\
\text { technique, Hadoop }\end{array}$ & $\begin{array}{l}\text { Proposed a prediction technic } \\
\text { with high accuracy. The ability } \\
\text { of bulk stowage of }\end{array}$ \\
\hline
\end{tabular}




\begin{tabular}{|c|c|c|c|}
\hline & & $\begin{array}{l}\text { framework, logistic } \\
\text { regression algorithm }\end{array}$ & $\begin{array}{l}\text { climatologically data, effective } \\
\text { query and analysis, environment } \\
\text { variation prediction. }\end{array}$ \\
\hline $\begin{array}{l}\text { Sankaralingam } \\
\text { et al. (2015) } \\
{[18]}\end{array}$ & $\begin{array}{l}\text { Big data and } \\
\text { data analytics }\end{array}$ & $\begin{array}{l}\text { Farm-level Management } \\
\text { Decisions, Landscape } \\
\text { Management Decisions }\end{array}$ & $\begin{array}{l}\text { Used to appraise how variations } \\
\text { in yield physiognomies, } \\
\text { controlling, and ecological } \\
\text { circumstances may impact crop } \\
\text { yields }\end{array}$ \\
\hline $\begin{array}{l}\text { Yadav, R. } \\
(2015)[19]\end{array}$ & Big data & $\begin{array}{l}\text { HDFS, Map Reduce, Hadoop, } \\
\text { STORM }\end{array}$ & $\begin{array}{l}\text { Sensing of soil and crops using } \\
\text { sensors and effective analysis of } \\
\text { big data transformed the farming } \\
\text { system to become much more } \\
\text { productive, less costly and to } \\
\text { produce a higher quality } \\
\text { agricultural product. }\end{array}$ \\
\hline $\begin{array}{l}\text { Forkan., et al } \\
(2015)[20]\end{array}$ & IOT, Big data & $\begin{array}{l}\text { Cloud based big data analysis } \\
\text { and data mining technique } \\
\text { where information reaches } \\
\text { former via mobile app. }\end{array}$ & $\begin{array}{l}\text { Using forecasted information to } \\
\text { increase agricultural production } \\
\text { and minimize the cost. }\end{array}$ \\
\hline $\begin{array}{l}\text { Li, X., Eckert, } \\
\text { M., et al } \\
(2015)[21]\end{array}$ & IOT & $\begin{array}{ll}\text { Context } & \text { Awareness } \\
\text { Application } & \end{array}$ & $\begin{array}{l}\text { Explains the power and weakness } \\
\text { of each approach to meaning } \\
\text { consciousness using IoT. }\end{array}$ \\
\hline $\begin{array}{l}\text { Channe, H., } \\
\text { Kothari, S., \& } \\
\text { Kadam, D. et } \\
\text { al (2015) [22] }\end{array}$ & $\begin{array}{l}\text { IOT, Data } \\
\text { analysis, } \\
\text { Cloud } \\
\text { computing }\end{array}$ & $\begin{array}{l}\text { Multidisciplinary model } \\
\text { focused on key technologies } \\
\text { for smart agriculture. }\end{array}$ & $\begin{array}{l}\text { Beneficial for improved } \\
\text { agricultural production and Agro- } \\
\text { product cost control. }\end{array}$ \\
\hline $\begin{array}{l}\text { Sravanthi, K., } \\
\& \quad \text { Subba } \\
\text { Reddy, } \quad \text { T. } \\
(2015)[23]\end{array}$ & Big data & Sensor data to optimize crop. & $\begin{array}{l}\text { To find out the environmental } \\
\text { conditions are optimal }\end{array}$ \\
\hline $\begin{array}{l}\text { Ramesh, D., \& } \\
\text { Vardhan, B. V. } \\
\text { (2015) [24] }\end{array}$ & $\begin{array}{lr}\text { Data } & \text { Mining } \\
\text { and } & \text { Data } \\
\text { analysis } & \\
\end{array}$ & $\begin{array}{l}\text { Multiple Linear Regression } \\
\text { technique }\end{array}$ & $\begin{array}{l}\text { Gives region specific crop yield } \\
\text { analysis. }\end{array}$ \\
\hline $\begin{array}{l}\text { Ravisankar et } \\
\text { al. (2016) [25] }\end{array}$ & $\begin{array}{l}\text { Big data and } \\
\text { meta data }\end{array}$ & $\begin{array}{l}\text { Sensor Cloud Infrastructure, } \\
\text { mobile services based on } \\
\text { sensor- cloud infrastructure }\end{array}$ & $\begin{array}{l}\text { used in the field of farming to } \\
\text { monitor the crop grounds to } \\
\text { maintenance it }\end{array}$ \\
\hline $\begin{array}{l}\text { Stubb, M. } \\
(2016)[26]\end{array}$ & Big data & $\begin{array}{l}\text { Data collection and } \\
\text { management }\end{array}$ & $\begin{array}{l}\text { Production Benefits, } \\
\text { Environmental Benefits, New } \\
\text { and Expanded Business } \\
\text { Opportunities }\end{array}$ \\
\hline $\begin{array}{l}\text { Ingale et al. } \\
(2016) \text { [27] }\end{array}$ & BIG DATA & $\begin{array}{l}\text { Precision Agriculture, } \\
\text { PREDICTIVE ANALYSIS }\end{array}$ & $\begin{array}{l}\text { Improve the analysis and } \\
\text { predictive decision making } \\
\text { power of actors related to the } \\
\text { agriculture sector. }\end{array}$ \\
\hline $\begin{array}{l}\text { Ribarics, } \quad \text { P. } \\
(2016)[28]\end{array}$ & big data & Predictive analytics & $\begin{array}{l}\text { Optimum irrigation, fertilization } \\
\text { and crop harvesting as well as } \\
\text { optimum livestock feeding and } \\
\text { delivery to market. }\end{array}$ \\
\hline $\begin{array}{l}\text { Carbonell, I. } \\
\text { M. (2016) [29] }\end{array}$ & Big Data & Predictive agriculture & $\begin{array}{l}\text { Informs the former regarding the } \\
\text { pesticides and germicides added } \\
\text { to his crops. }\end{array}$ \\
\hline $\begin{array}{l}\text { Nandyala, C. } \\
\text { S., \& Kim, H. } \\
\text { K. (2016) [30] }\end{array}$ & Big data & Sensor Cloud Infrastructure & Mobile Decision Taking systems. \\
\hline
\end{tabular}




\begin{tabular}{|c|c|c|c|}
\hline $\begin{array}{l}\text { Nalini N. et al. } \\
\text { (2017) [8] }\end{array}$ & $\begin{array}{l}\text { Data } \\
\text { Analytics, } \\
\text { IOT }\end{array}$ & $\begin{array}{l}\text { Sensor gathered information } \\
\text { from field level. Finding } \\
\text { unknown events and apply } \\
\text { findings to relevant } \\
\text { application. }\end{array}$ & $\begin{array}{l}\text { Seed choice, farm automation, } \\
\text { precision agriculture, soil } \\
\text { corrosion, Irrigation system. }\end{array}$ \\
\hline $\begin{array}{l}\text { Nayyar, A., \& } \\
\text { Puri, V. (2017) } \\
{[32]}\end{array}$ & $\begin{array}{l}\text { IOT, Cloud } \\
\text { computing }\end{array}$ & $\begin{array}{l}\text { IOT based smart farming and } \\
\text { precision agriculture. }\end{array}$ & $\begin{array}{l}\text { Provide farmers with more than } \\
99 \text { percent accurate results to help } \\
\text { them get reliable live feed from } \\
\text { ambient temperature and soil } \\
\text { moisture. }\end{array}$ \\
\hline $\begin{array}{l}\text { Nuvvula et al. } \\
(2017) \text { [33] }\end{array}$ & IoT & $\begin{array}{l}\text { Hydroponics, Controlled } \\
\text { Environment Agriculture } \\
\text { (CEA) }\end{array}$ & $\begin{array}{l}\text { The device can comparatively } \\
\text { simple to operate by the end } \\
\text { users, and can be applied in } \\
\text { small as well as large scale } \\
\text { agribusiness. }\end{array}$ \\
\hline $\begin{array}{l}\text { Marjani et al. } \\
(2017) \text { [34] }\end{array}$ & $\begin{array}{l}\text { Big data, data } \\
\text { analytics }\end{array}$ & Classification, clustering. & $\begin{array}{l}\text { Get moistness level of soil, stem } \\
\text { diameter of plants, micro } \\
\text { environment circumstances. }\end{array}$ \\
\hline $\begin{array}{l}\text { Maksimović et } \\
\text { al. (2017) [35] }\end{array}$ & $\begin{array}{l}\text { IoT and nano } \\
\text { technology }\end{array}$ & Green nano technology & $\begin{array}{l}\text { Making the farming segment and } \\
\text { food business more proficient, } \\
\text { harmless and viable }\end{array}$ \\
\hline $\begin{array}{l}\text { Bhavani et al. } \\
\text { (2017) [36] }\end{array}$ & $\begin{array}{l}\text { Big data } \\
\text { analytics }\end{array}$ & $\begin{array}{l}\text { Precision Agriculture } \\
\text { techniques }\end{array}$ & $\begin{array}{l}\text { Deliver technical holdup support } \\
\text { to the agriculturalists to } \\
\text { instrument advanced models that } \\
\text { are simulated in a large scale. }\end{array}$ \\
\hline $\begin{array}{l}\text { Rajeswari et } \\
\text { al. (2017) [37] }\end{array}$ & $\begin{array}{l}\text { Big data } \\
\text { analytics }\end{array}$ & $\begin{array}{l}\text { Predictive analytics, } \\
\text { Recommendation System, } \\
\text { Data Mining, Time series } \\
\text { analytic technique using Big } \\
\text { data }\end{array}$ & $\begin{array}{l}\text { Enhance productivity and reduce } \\
\text { manual inputs. }\end{array}$ \\
\hline $\begin{array}{l}\text { Gill et al. } \\
(2017)[38]\end{array}$ & $\begin{array}{l}\text { Big data } \\
\text { analytics }\end{array}$ & $\begin{array}{l}\text { Global Positioning System } \\
\text { (GPS), Yield monitoring and } \\
\text { mapping, Information } \\
\text { management, Variable-rate } \\
\text { Technology (VRT) }\end{array}$ & Accuracy agribusiness. \\
\hline $\begin{array}{l}\text { Al-kahtani, M. } \\
\text { S., \&Karim, L. } \\
\text { (2018) [39] }\end{array}$ & $\begin{array}{l}\text { Data } \\
\text { aggregation }\end{array}$ & $\begin{array}{l}\text { Data aggregation at layer } \\
\text { 1(Sensor network), layer } 2 \\
\text { (Base station - Internet), layer } \\
\text { 3(Response center - SQL } \\
\text { server) }\end{array}$ & $\begin{array}{l}\text { It reduces the complexity of data } \\
\text { analysis at the top layer. }\end{array}$ \\
\hline $\begin{array}{l}\text { Wolfert, S., } \\
\text { Ge, L., et al } \\
(2018)[40]\end{array}$ & Big data & Predictive yield model. & $\begin{array}{l}\text { Accomplish feed throughput in } \\
\text { livestock production, drive } \\
\text { working decisions in real time } \\
\text { and redesign business processes } \\
\text { for quicker, creative action and } \\
\text { commercial models that change } \\
\text { the game. }\end{array}$ \\
\hline $\begin{array}{l}\text { Liu, J., Chai, } \\
\text { Y., et al. } \\
(2018)[41]\end{array}$ & Data analytics & $\begin{array}{l}\text { Photovoltaic } r \text { systems, } \\
\text { bottlenecks and related } \\
\text { technologies for coupling } \\
\text { agriculture and clean energy } \\
\text { systems, covering multi-time } \\
\text { scale coupling, multi-system }\end{array}$ & 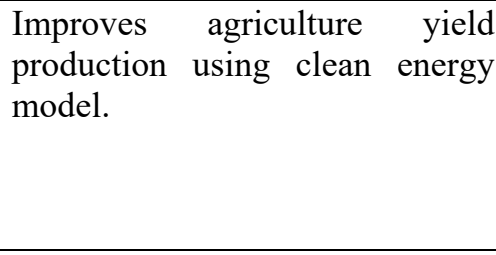 \\
\hline
\end{tabular}




\begin{tabular}{|c|c|c|c|}
\hline & & $\begin{array}{ll}\text { correlation } & \text { coupling } \\
\text { mechanisms } & \end{array}$ & \\
\hline $\begin{array}{l}\text { Aliev et al. } \\
(2018)[42]\end{array}$ & IoT, WSN & $\begin{array}{l}\text { nonlinear autoregressive } \\
\text { model, novel WSN approach, } \\
\text { predictive model }\end{array}$ & $\begin{array}{l}\text { Proficient to monitor ambient } \\
\text { temperature, moistness and soil } \\
\text { moisture. }\end{array}$ \\
\hline $\begin{array}{l}\text { Jerzak et al. } \\
\text { (2018) [43] }\end{array}$ & $\begin{array}{l}\text { Information } \\
\text { Technology }\end{array}$ & ICT enabled agriculture & $\begin{array}{l}\text { To well apprehend the role of } \\
\text { ICTs in India's future financial } \\
\text { development }\end{array}$ \\
\hline $\begin{array}{l}\text { Ngo et al. } \\
(2018)[44]\end{array}$ & $\begin{array}{l}\text { Data analysis, } \\
\text { Data } \\
\text { warehouse }\end{array}$ & $\begin{array}{l}\text { crop yield prediction, } \\
\text { precision agriculture }\end{array}$ & $\begin{array}{l}\text { System to efficiently handle } \\
\text { agricultural data Efficiently } \\
\text { forecast and improve crop yield. }\end{array}$ \\
\hline $\begin{array}{l}\text { Aher et al. } \\
(2018)[45]\end{array}$ & $\begin{array}{l}\text { Cloud } \\
\text { computing }\end{array}$ & $\begin{array}{l}\text { Fog computing, real time } \\
\text { processing }\end{array}$ & $\begin{array}{l}\text { Gives faster response in real time } \\
\text { applications and also reduces the } \\
\text { load on the cloud, less network } \\
\text { cost and reduced energy } \\
\text { consumption. }\end{array}$ \\
\hline $\begin{array}{l}\text { Coble, K. H., } \\
\text { et al }(2018) \\
{[46]}\end{array}$ & Big data & $\begin{array}{l}\text { Precision } \\
\text { Analytical method, applied } \\
\text { economics. }\end{array}$ & $\begin{array}{l}\text { Climate forecasting, crop yield } \\
\text { and crop selection prediction, } \\
\text { irrigation systems, prediction of } \\
\text { crop disease, agricultural policy } \\
\text { and trade. }\end{array}$ \\
\hline $\begin{array}{ll}\text { Kovács, I., \& } \\
\text { Husti, } & \text { I. } \\
(2018) \text { [47] }\end{array}$ & $\begin{array}{l}\text { IOT, Cloud } \\
\text { computing, } \\
\text { Big data }\end{array}$ & GPS, GIS & $\begin{array}{l}\text { Optimize crop yield and reduces } \\
\text { wastage. }\end{array}$ \\
\hline $\begin{array}{l}\text { Kumar M, H., } \\
\& \\
\text { Menakadevi, } \\
\text { T. (2018) [48] }\end{array}$ & Data analytics & $\begin{array}{l}\text { Apache Hadoop Framework } \\
\text { and its core elements. }\end{array}$ & $\begin{array}{l}\text { Precision farming provides } \\
\text { farmers with technical support for } \\
\text { implementing technology in } \\
\text { agriculture. And also found that } \\
\text { Hadoop is ideally suited to } \\
\text { processing large-scale data set for } \\
\text { agriculture. }\end{array}$ \\
\hline $\begin{array}{l}\text { B. Santhiya } \\
(2018)[49]\end{array}$ & $\begin{array}{l}\text { IOT } \\
\text { Cloud } \\
\text { computing }\end{array}$ & $\begin{array}{l}\text { Web based automatic control } \\
\text { system. }\end{array}$ & $\begin{array}{l}\text { Automates irrigation and } \\
\text { monitoring of plants in the terrace } \\
\text { garden }\end{array}$ \\
\hline $\begin{array}{l}\text { Sarker et al. } \\
(2019) \text { [50] }\end{array}$ & $\begin{array}{l}\text { Big data and } \\
\text { analytics }\end{array}$ & Digital agriculture & $\begin{array}{l}\text { Help farmers from the field } \\
\text { preparation to harvestings such } \\
\text { as weather forecasting, crop } \\
\text { yield prediction, agricultural } \\
\text { marketing and agricultural pest } \\
\text { management. }\end{array}$ \\
\hline $\begin{array}{l}\text { Jain, A., \& } \\
\text { Kumar, A. } \\
(2019)[51]\end{array}$ & IoT & $\begin{array}{l}\text { Sensor based data gathering } \\
\text { and processing }\end{array}$ & $\begin{array}{l}\text { Reduce costs and stimulate } \\
\text { normal growth productivity, } \\
\text { profitable and warm repairs. }\end{array}$ \\
\hline $\begin{array}{l}\text { Mathivanan, } \\
\text { S., \& } \\
\text { Jayagopal, P. } \\
(2019)[52]\end{array}$ & big data & Big data virtualization & $\begin{array}{l}\text { Plummeting the danger of data } \\
\text { mistake, capacity, progress, data } \\
\text { storage, policies and also an } \\
\text { increase in the speed of data } \\
\text { access }\end{array}$ \\
\hline $\begin{array}{l}\text { Surya, P., } \\
\text { \&Laurence } \\
\text { Aroquiaraj, I. } \\
(2019)[53]\end{array}$ & Data mining & $\begin{array}{l}\text { K-means and K-medoid } \\
\text { clustering algorithms. }\end{array}$ & $\begin{array}{l}\text { K-medoid clustering algorithm } \\
\text { achieved satisfactorily high } \\
\text { accuracy and lower error rate } \\
\text { compared to the clustering } \\
\text { algorithm k-means. By these } \\
\text { results k-medoids gave this }\end{array}$ \\
\hline
\end{tabular}




\begin{tabular}{|c|c|c|c|}
\hline & & & $\begin{array}{l}\text { Agriculture dataset a better } \\
\text { performance. }\end{array}$ \\
\hline $\begin{array}{l}\text { Anushree., et } \\
\text { al (2019) [54] }\end{array}$ & $\begin{array}{l}\text { wireless sensor } \\
\text { network }\end{array}$ & $\begin{array}{l}\text { A cloud-based } \\
\text { architecture }\end{array}$ & $\begin{array}{l}\text { The efficiency, productivity, and } \\
\text { profitability of many agricultural } \\
\text { production systems through the } \\
\text { use of Wireless Sensor Networks } \\
\text { (WSNs) would increase precision } \\
\text { agriculture. }\end{array}$ \\
\hline $\begin{array}{l}\text { Liu, S., Guo, } \\
\text { L., et al (2019) } \\
\text { [55] }\end{array}$ & $\begin{array}{l}\text { IoT, Data } \\
\text { analytics, } \\
\text { Data Mining }\end{array}$ & $\begin{array}{l}\text { Video surveillance approach, } \\
\text { Transmission and analysis } \\
\text { approach. }\end{array}$ & $\begin{array}{l}\text { Application is combination of } \\
\text { IoT, cloud computing and data } \\
\text { analytics. } \\
\text { Hybrid data stowage system is } \\
\text { designed. }\end{array}$ \\
\hline $\begin{array}{l}\text { Chen, J., \& } \\
\text { Yang, } \quad \text { A. } \\
(2019)[56]\end{array}$ & $\begin{array}{l}\text { IoT, data } \\
\text { visualization } \\
\text { analysis and } \\
\text { cluster } \\
\text { analysis. } \\
\end{array}$ & $\begin{array}{l}\text { Data visualization approach, } \\
\text { Cluster analysis approach }\end{array}$ & $\begin{array}{l}\text { Most relevant data was obtained } \\
\text { by front end visualization } \\
\text { technology. }\end{array}$ \\
\hline $\begin{array}{l}\text { Kamath, R., } \\
\text { Balachandra, } \\
\text { M., et al. } \\
(2019) \text { [57] }\end{array}$ & $\begin{array}{l}\text { WSN, } \\
\text { Data } \\
\text { classification }\end{array}$ & $\begin{array}{l}\text { Decision support system } \\
\text { approach, } \\
\text { wireless visual sensor network } \\
\text { approach, } \\
\text { Bluetooth 4.0, } \\
\text { Data classification. }\end{array}$ & $\begin{array}{l}\text { Bluetooth } 4.0 \text { can be used as } \\
\text { message technology, } \\
\text { Data sufferers can be condensed; } \\
\text { The excellence of images made is } \\
\text { very subtle and brittle well suited } \\
\text { for outside location. }\end{array}$ \\
\hline $\begin{array}{l}\mathrm{Hu}, \mathrm{Z} ., \mathrm{Xu}, \mathrm{L} . \text {, } \\
\text { Cao, L., et al. } \\
(2019)[58]\end{array}$ & WSN, IoT & $\begin{array}{l}\text { Non Orthogonal } \\
\text { Access (NOMA) }\end{array}$ & $\begin{array}{l}\text { Supports more user equipment's } \\
\text { simultaneously. } \\
\text { Supports high data transmission } \\
\text { rate and massive connectivity. }\end{array}$ \\
\hline $\begin{array}{l}\text { Tseng, F. H., } \\
\text { Cho, H. H., \& } \\
\text { Wu, H. T. } \\
(2019)[59]\end{array}$ & $\begin{array}{l}\text { IoT, Data } \\
\text { analytics }\end{array}$ & $\begin{array}{lrr}\text { Data cleaning } & \text { and } \\
\text { normalization, 3D } & \text { cluster } \\
\text { correlation analysis, } & \text { Crop } \\
\text { selection analysis } & \text { and } \\
\text { decision making. } & \\
\end{array}$ & $\begin{array}{l}\text { Analyzes cultivation techniques } \\
\text { practiced by customer, examines } \\
\text { environmental changes, choose } \\
\text { suitable crop for cultivation. }\end{array}$ \\
\hline $\begin{array}{l}\text { Farooq, M. S., } \\
\text { Riaz, S., Abid, } \\
\text { A., et al. } \\
(2019)[60],\end{array}$ & $\begin{array}{ll}\text { IoT, } & \text { Data } \\
\text { Mining, } & \text { Data } \\
\text { analytics } & \end{array}$ & $\begin{array}{l}\text { Cloud computing, Big data } \\
\text { storage and analytics. }\end{array}$ & $\begin{array}{l}\text { Network architecture, platform } \\
\text { and design helps access to IoT, } \\
\text { improves crop productivity, } \\
\text { Provides overview of IoT } \\
\text { applications, sensors, protocols } \\
\text { and data enabled technologies. }\end{array}$ \\
\hline $\begin{array}{l}\text { Tóth, M., } \\
\text { Felföldi, J., \& } \\
\text { Szilágyi, R. } \\
(2019)[61]\end{array}$ & $\begin{array}{l}\text { sensor } \\
\text { technology, } \\
\text { wireless } \\
\text { network, } \\
\text { IOT }\end{array}$ & $\begin{array}{l}\text { WSN, Remote Monitoring } \\
\text { System (RMS) }\end{array}$ & $\begin{array}{l}\text { Collecting real-time farm } \\
\text { construction environment data. }\end{array}$ \\
\hline $\begin{array}{l}\text { Rao, G. P. R., } \\
\text { Indira, V. V. } \\
\text { S., et al. } \\
(2019)[62]\end{array}$ & $\begin{array}{l}\text { IOT and data } \\
\text { analytics }\end{array}$ & $\begin{array}{l}\text { Centralized control unit for } \\
\text { sensors. }\end{array}$ & $\begin{array}{l}\text { Minimizes power consumption } \\
\text { for devices with IOT. }\end{array}$ \\
\hline $\begin{array}{l}\text { Rasooli, M. } \\
\text { W., Bhushan, } \\
\text { B., \& Kumar, } \\
\text { N. (2020) [63] }\end{array}$ & $\begin{array}{l}\text { WSN, data } \\
\text { analytics }\end{array}$ & $\begin{array}{l}\text { node sensors and web } \\
\text { application }\end{array}$ & $\begin{array}{l}\text { Optimal irrigation of the water for } \\
\text { farming crops. }\end{array}$ \\
\hline
\end{tabular}




\begin{tabular}{|c|c|c|c|}
\hline $\begin{array}{l}\text { Pini, } \quad \text { M., } \\
\text { Marucco, G., } \\
\text { et al. (2020) } \\
{[64]}\end{array}$ & $\begin{array}{l}\text { Wireless } \\
\text { sensor } \\
\text { network, data } \\
\text { analytics }\end{array}$ & $\begin{array}{l}\text { Global navigation satellite } \\
\text { system (GNSS), real time } \\
\text { kinematic (RTK) }\end{array}$ & $\begin{array}{l}\text { Provide the maximum level of } \\
\text { position correctness ( } \mathrm{cm} \text { range) } \\
\text { and precision for agricultural } \\
\text { tasks. }\end{array}$ \\
\hline $\begin{array}{l}\text { Saad, A., \& } \\
\text { Gamatié, A. } \\
(2020)[65]\end{array}$ & $\begin{array}{l}\text { Wireless } \\
\text { Sensor } \\
\text { Networks } \\
\text { (WSN), } \\
\text { Cyber- } \\
\text { Physical } \\
\text { System (CPS), } \\
\text { Cloud } \\
\text { Computing }\end{array}$ & $\begin{array}{l}\text { Renewable energy, Machine } \\
\text { learning using K-Means } \\
\text { clustering. Web and mobile } \\
\text { based applications, motion } \\
\text { detection devices }\end{array}$ & $\begin{array}{l}\text { It discourses usage of water in } \\
\text { agriculture. }\end{array}$ \\
\hline $\begin{array}{l}\text { Gupta, M., } \\
\text { Abdelsalam, } \\
\text { M., et al. } \\
(2020)[66]\end{array}$ & $\begin{array}{l}\text { IoT, cloud } \\
\text { computing, } \\
\text { Cyber Physical } \\
\text { System (CPS) }\end{array}$ & $\begin{array}{l}\text { Cloud based real time data } \\
\text { gathering and processing. }\end{array}$ & $\begin{array}{l}\text { Elaborates cyber security } \\
\text { challenges in smart farming. }\end{array}$ \\
\hline $\begin{array}{l}\text { Liu, R., Zhang, } \\
\text { Y., Ge, Y., Hu, } \\
\text { W., \& Sha, B. } \\
(2020) \text { [67] }\end{array}$ & $\begin{array}{l}\text { Cyber Physical } \\
\text { System (CPS), } \\
\text { Cloud } \\
\text { computing }\end{array}$ & $\begin{array}{l}\text { precision regulation model, } \\
\text { agriculture cyber physical } \\
\text { system (ACPS), PRMWFA- } \\
\text { ACPS MODEL: }\end{array}$ & $\begin{array}{l}\text { It improves water and fertilizer } \\
\text { regulations. }\end{array}$ \\
\hline $\begin{array}{l}\text { Gulec, } \quad \text { O., } \\
\text { Haytaoglu, E., } \\
\& \text { Tokat, S. } \\
(2020)[68]\end{array}$ & $\begin{array}{l}\text { WSN, Solar } \\
\text { energy system. }\end{array}$ & Image processing technique. & $\begin{array}{l}\text { Prevents data loss and collusion, } \\
\text { increases the lifetime of WSN. }\end{array}$ \\
\hline $\begin{array}{l}\text { Huang, K., } \\
\text { Shu, L., Li, K., } \\
\text { Yang, F., et al. } \\
(2020)[69]\end{array}$ & $\begin{array}{l}\text { Photovoltaic } \\
\text { agriculture. } \\
\text { IoT, Big data }\end{array}$ & PAIoT & $\begin{array}{l}\text { Solves the problem of an energy } \\
\text { shortage, Use of renewable } \\
\text { energy sources. }\end{array}$ \\
\hline $\begin{array}{l}\text { Balamurugan., } \\
\text { et al. (2020) } \\
{[70]}\end{array}$ & $\begin{array}{l}\text { big data } \\
\text { analytics }\end{array}$ & $\begin{array}{l}\text { Supervised and no supervised } \\
\text { learning models, Linear } \\
\text { regression, Map Reduce } \\
\text { Algorithms }\end{array}$ & $\begin{array}{l}\text { Better decision support system, } \\
\text { water and other resource } \\
\text { management. }\end{array}$ \\
\hline
\end{tabular}

\section{NEW RELATED ISSUE IN SMART AGRICULTURE :}

Smart agriculture contributes to precise agriculture that focuses on context-consciousness in the agricultural sector, both at the field and market-level [71].

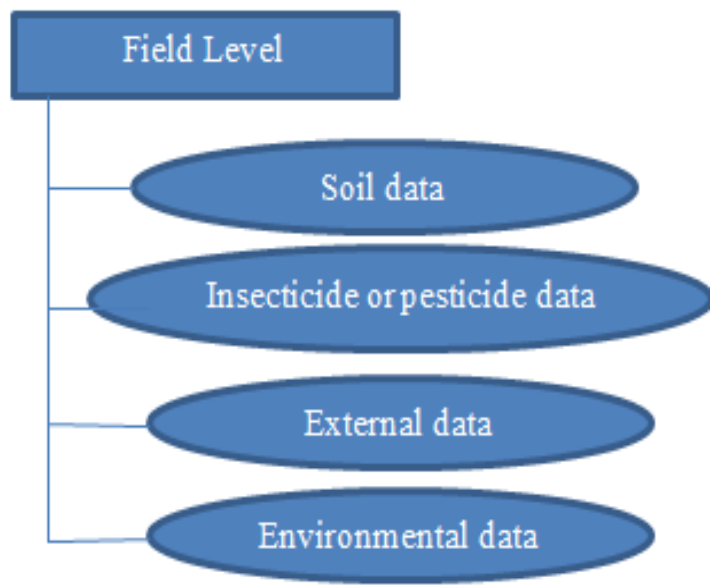

Fig. 3: Field level context awareness data 
Field level data are soil data, insecticide data, external data, and environmental data, as shown in figure 3. Soil data give soil type, soil water content, soil fertilizer content, etc. Data on insecticides or pesticides provide information on how much crop was affected by the pesticide. External data provide information on animal or bird attacks on the field. Environmental data include data on temperature, humidity, and rain data and so on. The data on the price of the crop, the price of the agricultural machine, the price of farm equipment and market price forecast for the next year as shown in figure 4 are given in market level data. The problems related to data collection and analyses occur here. Different sensors and wireless sensor networks need to be used to collect data from the field level. To access business data, the current data collection must be used from the cloud [72]. Both these field level data accessed by sensors and market level data accessed from database are essential data that constitute big data that plays a major role in smart agriculture system.

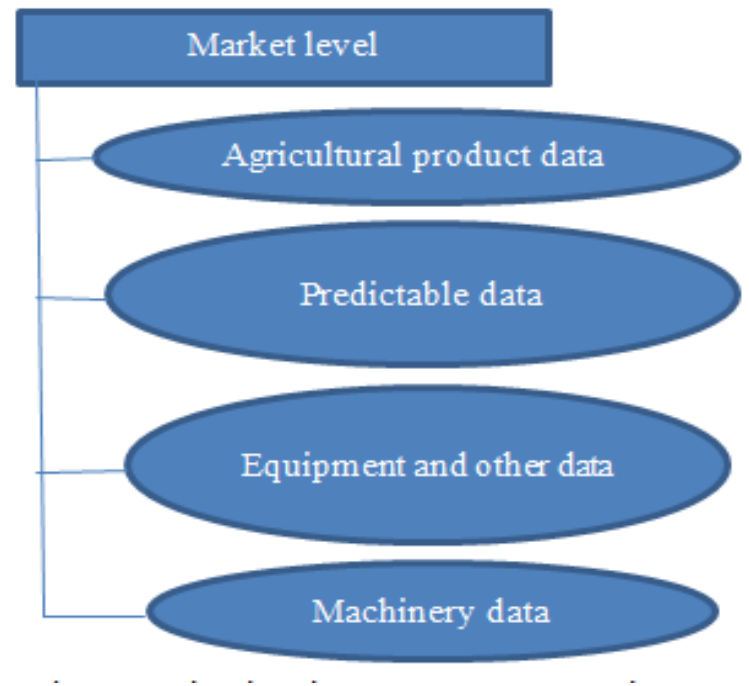

Fig. 4: Market level context awareness data

\section{THE IDEAL SOLUTION AND PROPOSED ARCHITECTURE :}

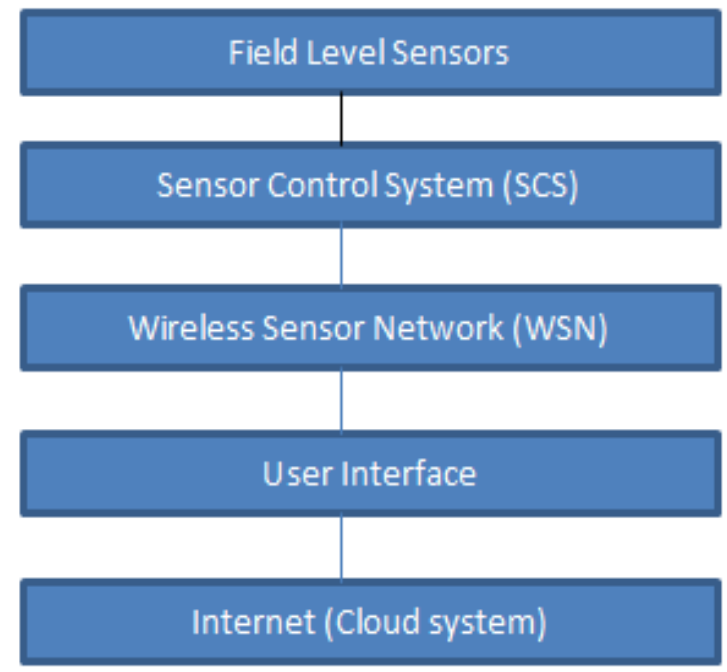

Fig. 5: hierarchical architecture of smart agriculture system 
Our proposed smart agriculture system architecture has 5 layers, as shown in Figure 5. Here, the field level sensors are the topmost layer, and the user interface is the bottommost layer. Here field-level sensors such as temperature sensors, soil sensors, water level sensors, moisture sensors, a rain detector sensor, and object detector sensors are mounted in the field performing their role. A device called the Sensor Control System (SCS) controls all of these different sensors. This SCS supplies various sensors with the necessary power and collects data from it using the Wireless Sensor Network (WSN) [73]. All of these data collected from various sensors will be stored via the internet in a cloud environment. Such field-level and business data will then be processed and displayed in the UI layer.

\section{IMPLEMENTATION :}

Within the smart agriculture architecture at what point, we must see which technique is best for implementation in each layer. The numerous field-level sensors such as temperature sensors, water level sensors, moisture sensors, soil sensors and object detector sensors are mounted on the field at different positions starting from the top level. In the second level Sensor Control System (SCS) requires a system board with ARM MCU, which acts as a system for data acquisition and control.

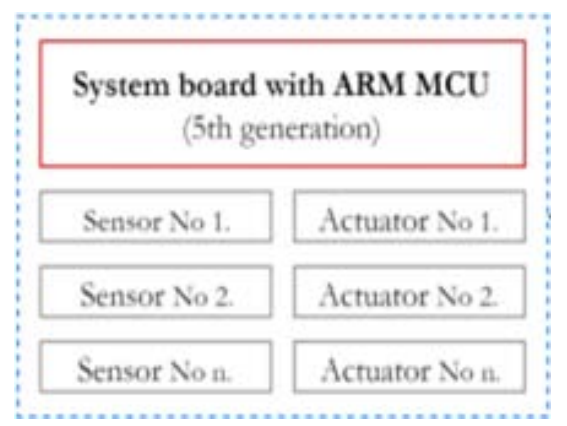

Fig. 6: Data acquisition and control system

It will collect all sorts of data from various sensors and monitor all the sensors from a centralized location. Wireless Sensor Network (WSN) can be used to implement a centralized system, as shown in Figure 6. This network of wireless sensors can be deployed using either the Wi-Fi or Zigbee network. Through this centralized control system, the farmer may use the Internet of Things (IoT) concept.

As shown in Figure 7 through the sensor, different types of data forms of agricultural land have been collected and stored in a cloud server, and market-level data such as current price and previous price are also stored on the cloud server. You can deploy this cloud server using AWS, Microsoft, IBM, and Watson. Cloud storage data are used for analysis by applying various data processing techniques such as SAS, SPSS, HADOOP, IBM Bluemix. After review, the result will be shown in the local system's user interface. The UI can be built using any programming language, such as. Net, PHP, Java [74].

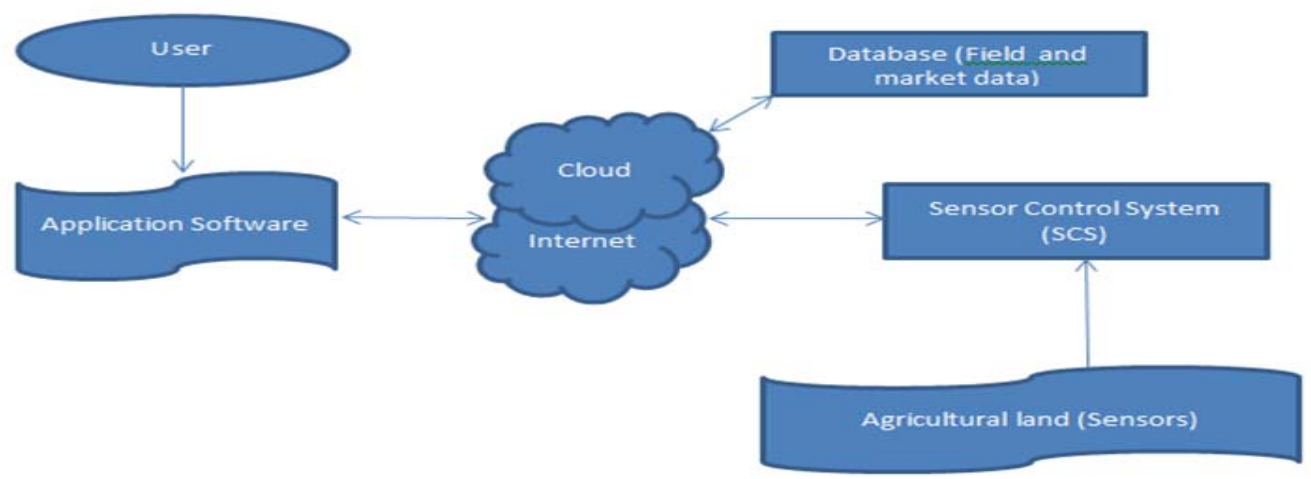

|Fig.7: conceptual view of smart agricultural system 


\section{IMPLEMETATION OF IoT AND DATA ANLYTICS IN SMART AGRICULTURE :}

The smart farming system consists of an architecture based on IoT and data analytics which mainly comprises 3 layers.

1. Front-End Layer: This is composed of sensors and a sensor control system. Which access data from sensors placed in agricultural land and also controls the sensors.

2. Gateway Layer: here the internet acts as a gateway layer, the sensed data will be transmitted to the backend layer through the gateway layer.

3. Back-End Layer: Here the cloud server will act as a backend layer. All field level and market data stored in the server end, which is than can be analyzed and displayed in the user interface.

The idea of IoT can be accomplished with the use of a sensor and wireless sensor network in the front end layer. Use data available in the backend layer or cloud service that has been processed, analyzed and presented in the user interface, so that in our proposed framework we can achieve the data analytics concept [75].

\section{BIG DATA AND DATA ANALYTICS IN SMART AGRICULTURE :}

Big data and data analytics play a crucial role in a smart farming cycle involving historical and present data providing better services through data mining. Big data in agriculture cover farm fields such as temperature data, humidity data, soil data, insecticide data, and other sensor data obtained from sensors. It also contains market data, such as trade data on commodities, financial forecast data, machinery and equipment [76]. Some areas where big data technologies have a huge influence on agriculture are, it improves estimating of development and output of agricultural process, quality of seeds and livestock, real-time decisions and alerts based on data from the field, helping predict future risk, integrated production and business management [77]. We'll gather data from different yields with the aid of IoT. With the aid of data analytics, we will analyse the bulky data sets to infer the favourable yield conditions to grow [78]. Big data include dominant technologies, such as HDFS, Map Reduce, Hadoop, Storm, for processing this broad agricultural data set. [79].

- Hadoop: It is an open-source system that stores a large number of data based on a distributed computing model [80]. It stores data in multiple nodes, thus protecting data and applications from fault. When any node fails, this will move it to another node [81]. Apache Hadoop software library is a platform that uses a simple programming model to enable distributed computation of large data sets across a cluster of computers [82]. Hadoop Distributed File System (HDFS) and Hadoop MapReduce are two principal components of the Hadoop architecture [83].

- HDFS: It manages large files, which are split into small frames and stored in multiple data nodes, and then performs sequential read / write operations [84]. Name node serves as focal points keeping track of the overall layout of the directory and monitoring frames. As shown in figure 8 , a data node reports all the frames to the name node [85].

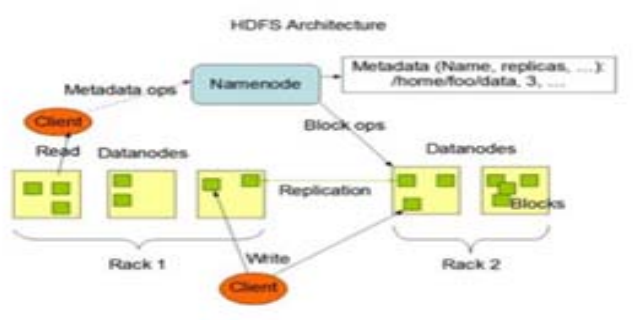

Fig. 8: HDFS Architecture [86]

To read the file, a client API sends file pointer frame indexes to the Name node as a request. As a result name node must address every data node that has the file replica. The application API interacts with the name node for the granting of data nodes that serve as a primary to write a file [87]. The client is updating its changes to all Data Nodes, but this apprises are stored in a distinct Data Node buffer. After all the changes in Data Nodes, the client will then send a "Commit" appeal 
to the primary which will decide an instruction to apprise all secondary Nodes. When secondary nodes complete an operation commit, primary will send a response about its progress to the client.

- MapReduce: It has two functions that are likely to combine and reduce function as seen in Figure 9. Once a client program submits task outline to the job tracker it begins execution. The job tracker's role is to pick multiple frames and task trackers based on its network [88]. The work tracker then sends requests for assignments to the selected task tracker. The mission tracker collects and separates data from inputs and performs a map processing function. When the work tracker is complete it notifies the job tracker. Then the work tracker selects to alert any activity tracker to perform the reduction function. Each task tracker reads the local file if crashes occur during the map and reduce its assai function. Each task tracker reads the local files if any crashes happen during the map and reduce function it assigns the task to another task tracker in the network. If both the map and reduce phase complete its execution than only the job tracker will unblock the client program [89].

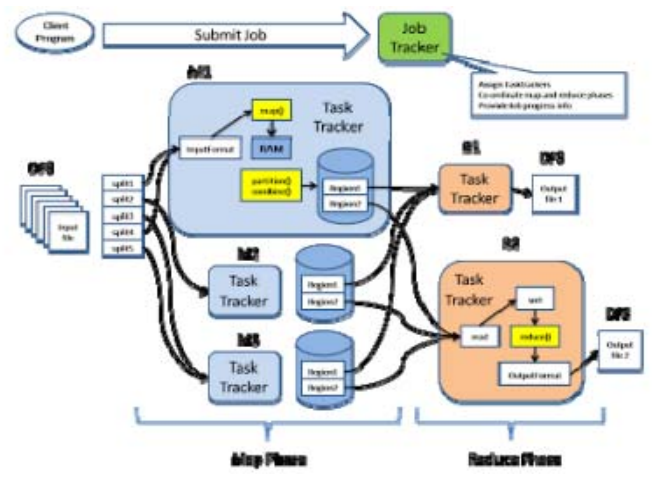

Fig. 9: Map Reduce phase in Hadoop [90]

\section{RESEARCH GAP :}

The implementation and integration of new advanced technologies to develop a smart system in agriculture allow farmers to monitor and control the agricultural process. These are the new research challenges that will benefit society both in the economic, social, and technical aspects. Forthcoming research in smart agricultural system will combine advanced technologies such as wireless sensor networks (WSN), Internet of Things (IoT), and data analytics. The IoT module is mainly used to gather environmental data and data analytics modules are mainly used to process and analyze the already existing data. This also embraces migration to new technologies based on the type of land, the type of crop, environmental conditions. The necessary training is required for both landowners and farmers in order to the effective utilization of the system. In our assessment, we observed that a smart agriculture system will produce enough information from large amounts of data from the sensors and database that help to carry the decision-making process. The smart agriculture system is necessary to step up the lifestyle of the farmers by improving economic conditions. Some of the research gap issues we found here.

Research Gap 1: IoT based application to collect environmental data from agricultural land. The agricultural land located in different parts of the geographical area has its own characteristics and behavior. The type of crop cultivation will vary according to place because of different climate conditions. So the agricultural product will decide the income of the farmer. Some geographical area farmers are rich because they cultivate income-generated products. However, farmers are poor in some geographical areas. So this technology helps minimize cost, improves the quality of the whole agricultural process and product management. A new application model was created based on the type of land, climate, soil, product, and place, what agricultural product improves the economic condition of the former. For bettering farmers in various parameters a new IoT based devices are necessary to improve farmer's economic background.

Research Gap 2: Wireless Sensor Network (WSN) based application to transmit data. Transmitting appropriate data to the right place is essential in real-time applications. Transmitting environmental data involve multiple factors of data aggregation, classification, and modeling. The technology also ensures 
the accuracy and privacy of the data during transmission. For this reason, a suitable network must transmit data from the field node to the base station. A reliable wireless sensor network should be established with various factors such as quality, privacy, availability and low power consumption, and should be feasible to the farmer.

Research Gap 3: The proper data analytical techniques to solve real-time problems. The data gathered from sensor nodes or from the cloud database are effective and meaningful only when it was properly processed and analyzed using the proper technique. Depends on the type and nature of the data obtained we must adopt appropriate data analysis techniques that should meet real-time requirements. So the appropriate data analytics techniques will help farmers get specific information that will lead them to take certain actions to further improve their agricultural process. Technology should not replace farmers but it should assist them toward positive change.

Research Gap 4: Requires user interface design to display analyzed results. The main aim of the system is to display the analyzed result in the proper user interface that supports all types of devices. The entire system's work is said to be successful if it can able to convey results in user understandable format through a proper interface. So in smart agriculture system with a proper user interface is also a key concept while developing the entire system.

\section{RESEARCH AGENDA :}

(1) What procedures and approaches were used to gather and process data from sensors and databases?

(2) What framework is used to integrate IoT and data analytics to achieve a smart agriculture system?

(3) What new technology can be proposed from in IoT and data analytics perspective to achieve better results in a smart agricultural system?

(4) What Wireless Sensor Network (WSN) technology can be suggested for the agricultural sector by considering software, hardware and network complexities?

(5) What farming strategies have evolved in the smart agriculture system, still continues to improve?

(6) What are the challenges in the implementation of different technologies in the agricultural process?

(7) What IoT and data analytics architecture recommend low cost, reliable technologies that make more benefits for farmers in rural areas.

\section{ANAL YSIS OF RESEARCH AGENDAS :}

The different procedures and approaches can be used to gather and process the data in a smart agricultural system that provides expected results. We must select the appropriate technique that meets all aspects of the social scene. The development of a framework to integrate both IoT and Data analytics is to be developed with the best suitable existing hardware and software. There should be a need to survey and analyze the existing current technology in both IoT and data analytics to achieve a better result in smart agriculture. The research is mainly focused on selecting the best technology in WSN, IoT and data analytics that gives solutions based on available data at low cost, reliable and should make benefit farmers worldwide. The implementation of data analysis technology is challenging in agriculture because the data are not the same for all crops. So based on the nature and type of data, one should find a relevant method for data analytics. The farmer can adopt any strategies during the farming process to achieve maximum profit. He can perform the farming process based on different parameters such as soil conditions, weather conditions, water availability, and price of the commodity. So here essential to provide this information well in advance to farmers to help them take the decision to perform the farming process. The prediction of all this parametric information is the biggest challenge that needs to be experiment in the later stage. The yield prediction and price prediction are useful for farmers worldwide to perform the farming process without having the risk of a fall in yield and price. So the fulfillment of this entire research agenda will help farmer's community in the entire world and thus we achieve good work by contributing to a large number of populations. 


\section{FINAL RESEARCH PROPOSAL IN CHOSEN TOPIC :}

Alternate approach for smart agriculture using crop yield prediction and price prediction using data analysis techniques.

\section{ABCD ANALYSIS OF RESEARCH PROPOSAL :}

$\mathrm{ABCD}$ framework is used to analyze the characteristics of the system or effectiveness of the idea and strategies while studying business value in society. It is mainly used to determine the various factors for the chosen determinant issues under four constructs called an advantage, benefits, constraints and disadvantages [91-92].

(a) Advantages:

- It supports an advanced method for agricultural practice.

- Improves the lifestyles of the farmer by adopting a new approach in agriculture.

- Well in advance it informs farmers about crop yield and market price.

- Prediction system helps farmers to undertake appropriate decisions.

- Extraction of information from the already available dataset using current advanced technology.

- Overcomes all the problems faced by farmers in traditional agriculture.

(b) Benefits:

- It is useful to farmer's communities all over the world.

- All the stakeholders of the agriculture business will be benefitted by this approach.

- Prediction system helps to predict future conditions of soil, weather, water, pesticides and market price.

(c) Constraints:

- The availability of data and data format is different for different crops.

- Sometimes the prediction accuracy depends on other global parameters.

- Initial cost required to establish the system.

- Migration from the traditional approach to smart agriculture.

- Selection of existing data analytics technology to process available data.

(d) Disadvantages:

- The accuracy of the analytical approach mainly depends on the available data.

- The equipment used is not reliable and it is prone to failure.

- End-user must have some knowledge about the system for its convenience.

- The result of the prediction will become false that lead to misinterpretation.

\section{SUGGESTIONS TO IMPLEMENT RESEARCH ACTIVITY :}

To get proper outcomes from agricultural land, we must analyze the conditions and circumstances in the right way. A proper understanding of the elements of agriculture, such as temperature, humidity, water level, rainfall, soil conditions, external animal threat, internal market conditions, and certain other parameters leads to the development of a smart agricultural system. To achieve this integration of agricultural elements and technology must be initially identified. This smart agriculture system will create a type of atmosphere that enables farmers to conduct a new type of agriculture that enables us to achieve reliability and profitability. In this information and communication technology scenario, the Internet of Things (IoT) and data analytics plays a major role, which helps achieve the proposed system. These 2 technologies convert all processes of real-world into smart and intelligent processes. The ability of the technology to script, search, and identify different objects leads the company to perform more efficient, fast, less error and flexible processing structures and techniques to implement IoT and data analytics. This research and literature review provides an important idea regards the process of making a smart agricultural system. They are simple technical skills that the farmer must learn and adapt to their daily routine. As part of future work, smart infrastructure has transformed agriculture into smart farming, and we must make it simpler so that all farmers can benefit from it as part of agriculture. In smart farming, IoT, sensors, cloud computing, data analytics, data mining, web applications, and mobile applications are permutations. Therefore, all these aspects of smart agriculture need to be focused on in the future. 


\section{CONCLUSION :}

A sector like agriculture should improve through the implementation of advanced technologies such as the Internet of Things (IoT) and data analytics. It helps achieve precision farming that allows farmers to get more accurate information on both on the field and off-field agriculture. The two main aspects of agriculture are context awareness, and fault tolerance can be achieved. The availability of the most accurate and effective sensors and the availability of internet facilities in all parts of the agricultural land could rectify all of these. So I conclude that the population of the Indians and world is growing exponentially, so the whole world is anticipating food, so we must grow more agricultural crops to meet the requirements of the world by implementing advanced technologies in agricultural practice.

\section{REFERENCES :}

[1] Patil, V. C., Al-Gaadi, K. A., Biradar, D. P., \& Rangaswamy, M. (2012). Internet of things (IoT) and cloud computing for agriculture: An overview. Proceedings of agro-informatics and precision agriculture (AIPA 2012), India, 292-296.

[2] Patil, K. A., \& Kale, N. R. (2016, December). A model for smart agriculture using IoT. In 2016 International Conference on Global Trends in Signal Processing, Information Computing and Communication (ICGTSPICC), 543-545.IEEE.

[3] Veena, S., Mahesh, K., Rajesh, M., \& Salmon, S. (2018). The survey on smart agriculture using IOT. Int J Innov Res EngManag (IJRIREM), 5(2), 63-66.

[4] Chauhan, N., Krishnakanth, M., Kumar, G. P., Jotwani, P., Tandon, U., Gosh, A., ...\& Santhi, V. (2019, March). Crop Shop-An application to maximize profit for farmers. In 2019 International Conference on Vision Towards Emerging Trends in Communication and Networking (ViTECoN), 1-7. IEEE.

[5] Barcelo-Ordinas, J. M., Chanet, J. P., Hou, K. M., \&García-Vidal, J. (2013). A survey of wireless sensor technologies applied to precision agriculture. In Precision agriculture'13, 801-808. Wageningen Academic Publishers, Wageningen.

[6] Mallick, C., \& Satpathy, S. (2018). Challenges and Design Goals of Wireless Sensor Networks: A State-of-the-art Review. International Journal of Computer Applications, 179(28), 42-47.

[7] Hung, M. C., Wu, J., Chang, J. H., \& Yang, D. L. (2005). An efficient k-means clustering algorithm using simple partitioning. Journal of information science and engineering, 21(6), 1157-1177.

[8] Nalini, N., \& Suvithavani, P. (2017). A Study on Data Analytics: Internet of Things \&HealthCare. International Journal of Computer Science and Mobile Computing (IJCSMC), 6(3), 20-27.

[9] Sawaitul, S. D., Wagh, K. P., \& Chatur, P. N. (2012). Classification and prediction of future weather by using back propagation algorithm-an approach. International Journal of Emerging Technology and Advanced Engineering, 2(1), 110-113.

[10] Jagyasi, B., Mohite, J., \& Pappula, S. (2013). Applications of mobile sensing technologies in precision agriculture. CSI Communications, 18(1), 21-23.

[11] Li, D., Zheng, Y., \& Zhao, W. (2019). Fault analysis system for agricultural machinery based on big data. IEEE Access, 7, 99136-99151.

[12] Kang, H. H., Lee, Y. J., \& Han, W. O. (2009). Energy-Efficient Hierarchical Cluster-Based Routing for Ubiquitous Sensor Networks. The Journal of the Korea institute of electronic communication sciences, 4(3), 243-246.

[13] Mahmood, T., \&Afzal, U. (2013, December). Security analytics: Big data analytics for cybersecurity: A review of trends, techniques and tools. In 2013 2nd national conference on Information assurance (ncia), 129-134.IEEE. 
[14] Yang, Y., \& Chen, W. (2016). Taiga: performance optimization of the C4. 5 decision tree construction algorithm. Tsinghua Science and Technology, 21(4), 415-425.

[15] Jeong, S., Jeong, H., Kim, H., \& Yoe, H. (2013). Cloud computing based livestock monitoring and disease forecasting system. International Journal of Smart Home, 7(6), 313-320.

[16] Medar, R. A., \& Rajpurohit, V. S. (2014). A survey on data mining techniques for crop yield prediction. International Journal of Advance Research in Computer Science and Management Studies, 2(9), 59-64.

[17] Parthasarathy, N. I. D. V. (2017). Evaluation and Management of Soil Fertility. International Journal of Pure and Applied Mathematics, 117(8), 11-15.

[18] Sankaralingam, B. P., \& Sarangapani, U. (2016). Agronomic-meteorological model for weather forecasting to predict the rainfall using machine learning techniques. International Journal of Convergence Computing, 2(2), 183-192.

[19] Yadav, R., Rathod, J., \& Nair, V. (2015). Big data meets small sensors in precision agriculture. International Journal of Computer Applications, 975(1), 8887 - 8895.

[20] Forkan, A. R. M., Khalil, I., Ibaida, A., \& Tari, Z. (2015). BDCaM: Big data for context-aware monitoring-A personalized knowledge discovery framework for assisted healthcare. IEEE transactions on cloud computing, 5(4), 628-641.

[21] Li, X., Eckert, M., Martinez, J. F., \& Rubio, G. (2015). Context aware middleware architectures: survey and challenges. Sensors, 15(8), 20570-20607.

[22] Channe, H., Kothari, S., \& Kadam, D. (2015). Multidisciplinary model for smart agriculture using internet-of-things (IoT), sensors, cloud-computing, mobile-computing \& big-data analysis. Int. J. Computer Technology \& Applications, 6(3), 374-382.

[23] Sravanthi, K., \& Reddy, T. S. (2015). Applications of big data in various fields. International Journal of Computer Science and Information Technologies, 6(5), 4629-4632.

[24] Ramesh, D., \& Vardhan, B. V. (2015). Analysis of crop yield prediction using data mining techniques. International Journal of research in engineering and technology, 4(1), 47-473.

[25] Ravisankar, K., Sidhardha, K., \& Prabadevi, B. (2017). Analysis of agricultural data using big data analytics. Journal of Chemical and Pharmaceutical Sciences, 10(3), 1132-1135.

[26] Stubb, M. (2016). Big data in US agriculture. Washington, DC: Congressional Research Service.

[27] Ingale, V. B., \& Jadhav, D. K. (2016). Big Data A Great Revolution in Precision Agriculture using Predictive Weather Analysis and Soil Analysis. International Journal of Agriculture Innovations and Research, 5(3), 410-412.

[28] Ribarics, P. (2016). Big Data and its impact on agriculture. Ecocycles, 2(1), 33-34.

[29] Carbonell, I. (2016). The ethics of big data in big agriculture. Internet Policy Review, 5(1), 31-39.

[30] Nandyala, C. S., \& Kim, H. K. (2016). Big and meta data management for U-agriculture mobile services. Int. J. Software Eng. Appl. (IJSEIA), 10(1), 257-270.

[31] Kamilaris, A., Kartakoullis, A., \& Prenafeta-Boldú, F. X. (2017). A review on the practice of big data analysis in agriculture. Computers and Electronics in Agriculture, 143(1), 23-37.

[32] Nayyar, A., \& Puri, V. (2016, September). Smart farming: IoT based smart sensors agriculture stick for live temperature and moisture monitoring using Arduino, cloud computing \& solar technology. In Proc. of The International Conference on Communication and Computing Systems (ICCCS2016) (pp. 9781315364094-121). 
[33] Nuvvula, J., Adiraju, S., Mubin, S., Shahana, B., \& Valisetty, V. (2017). Environmental Smart Agriculture Monitoring System Using Internet of Things. International Journal of Pure and Applied Mathematics, 115(6), 313-320.

[34] Marjani, M., Nasaruddin, F., Gani, A., Karim, A., Hashem, I. A. T., Siddiqa, A., \& Yaqoob, I. (2017). Big IoT data analytics: architecture, opportunities, and open research challenges. IEEE Access, 5, 5247-5261.

[35] Maksimović, M., \& Omanović-Mikličanin, E. (2017). Green internet of things and green nanotechnology role in realizing smart and sustainable agriculture. In VIII international scientific agriculture symposium “AGROSYM 2017, 2290-2295.

[36] Bhavani, D. D., \& Bharati, R. B. S. (2017). An Efficient Method to Incorporate Precision Farming in Indian Agriculture Using Robotics and Internet of Things. International Journal of Research in IT \& Management, 6(9), 71-79.

[37] Rajeswari, S., Suthendran, K., \& Rajakumar, K. (2017, June). A smart agricultural model by integrating IoT, mobile and cloud-based big data analytics. In 2017 international conference on intelligent computing and control (I2C2), 1-5. IEEE.

[38] Gill, S. S., Chana, I., \& Buyya, R. (2017). IoT based agriculture as a cloud and big data service: the beginning of digital India. Journal of Organizational and End User Computing (JOEUC), 29(4), 123.

[39] Al-Kahtani, M. S., \& Karim, L. (2018). Dynamic data aggregation approach for sensor-based big data. International Journal of Advanced Computer Science and Applications (IJACSA), 9(7), 62-72.

[40] Wolfert, S., Ge, L., Verdouw, C., \& Bogaardt, M. J. (2017). Big data in smart farming-a review. Agricultural Systems, 153(1), 69-80.

[41] Liu, J., Chai, Y., Xiang, Y., Zhang, X., Gou, S., \& Liu, Y. (2018). Clean energy consumption of power systems towards smart agriculture: roadmap, bottlenecks and technologies. CSEE Journal of Power and Energy Systems, 4(3), 273-282.

[42] Aliev, K., Pasero, E., Jawaid, M. M., Narejo, S., \& Pulatov, A. (2018). Internet of plants application for smart agriculture. Int J AdvComputSciAppl, 9(4), 421-429.

[43] Jerzak, M., Smiglak-Krajewska, M., Czerwinska-Kayzer, D., \& Florek, J. (2018). The market for native protein crops as a factor in improving food security in Poland. In Agrarian Perspectives XXVII. Food Safety-Food Security, Proceedings of the 27th International Scientific Conference, 19-20 September 2018, Prague, Czech Republic (pp. 81-86). Czech University of Life Sciences Prague, Faculty of Economics and Management.

[44] Ngo, V. M., Le-Khac, N. A., \& Kechadi, M. (2018). An efficient data warehouse for crop yield prediction. arXiv preprint arXiv:1807.00035.

[45] Aher, A., Kasar, J., Ahuja, P., \&Jadhav, V. (2018). Smart agriculture using clustering and IOT. International Research Journal of Engineering and Technology (IRJET), 5(03), 4065-4068.

[46] Coble, K. H., Mishra, A. K., Ferrell, S., \& Griffin, T. (2018). Big data in agriculture: A challenge for the future. Applied Economic Perspectives and Policy, 40(1), 79-96.

[47] Kovács, I., \& Husti, I. (2018). The role of digitalization in the agricultural 4.0-how to connect the industry 4.0 to agriculture?. Hungarian Agricultural Engineering, 33(1), 38-42.

[48] Kumar, H., \& Menakadevi, T. (2018). A review on big data analytics in the field of agriculture. International Journal of Latest Transactions in Engineering and Science, 1(4), 1-10. 
[49] Santhiya, B., Govindharaj, I., Soundharya, C., Priyanka, R., Rajadurai, R., Maduravani, B., \& Shanmukhi, M. (2018). Smart Monitoring of Tarrace Garden using Solar Energy. International Journal of Pure and Applied Mathematics, 118(14), 387-392.

[50] Sarker, M. N. I., Islam, M. S., Ali, M. A., Islam, M. S., Salam, M. A., \& Mahmud, S. H. (2019). Promoting digital agriculture through big data for sustainable farm management. International Journal of Innovation and Applied Studies, 25(4), 1235-1240.

[51] Priya, P. L. V., Harshith, N. S., \& Ramesh, D. N. (2018). Smart agriculture monitoring system using IoT. International Journal of Engineering \& Technology, 7(2.7), 308-311.

[52] Mathivanan, S., \& Jayagopal, P. (2019). A Big Data Virtualization Role in Agriculture: A Comprehensive Review. Walailak Journal of Science and Technology (WJST), 16(2), 55-70.

[53] Surya, P., \& Laurence Aroquiaraj, I. (2019). Performance Analysis of K-Means and K-Medoid Clustering Algorithms Using Agriculture Dataset. Journal of Emerging Technologies and Innovative Research (JETIR), 6(1), 539-545.

[54] Anushree, M. K., \& Krishna, R. (2018). A smart farming system using Arduino based technology. Int. J. Adv. Res. Ideas Innov. Technol, 4(4), 850-856.

[55] Liu, S., Guo, L., Webb, H., Ya, X., \& Chang, X. (2019). Internet of Things monitoring system of modern eco-agriculture based on cloud computing. IEEE Access, 7(1), 37050-37058.

[56] Chen, J., \& Yang, A. (2019). Intelligent agriculture and its key technologies based on internet of things architecture. IEEE Access, 7(1), 77134-77141.

[57] Kamath, R., Balachandra, M., \& Prabhu, S. (2019). Raspberry pi as visual sensor nodes in precision agriculture: A study. IEEE Access, 7(1), 45110-45122.

[58] Hu, Z., Xu, L., Cao, L., Liu, S., Luo, Z., Wang, J., ...\& Wang, L. (2019). Application of nonorthogonal multiple access in wireless sensor networks for smart agriculture. IEEE Access, 7(1), 8758287592.

[59] Tseng, F. H., Cho, H. H., \& Wu, H. T. (2019). Applying big data for intelligent agriculture-based crop selection analysis. IEEE Access, 7(1), 116965-116974.

[60] Farooq, M. S., Riaz, S., Abid, A., Abid, K., \&Naeem, M. A. (2019). A Survey on the Role of IoT in Agriculture for the Implementation of Smart Farming. IEEE Access, 7(1), 156237-156271.

[61] Tóth, M., Felföldi, J., \&Szilágyi, R. (2019). Possibilities of IoT based management system in greenhouses. Georgikon for Agriculture, 23(3), 43-62.

[62] Rao, G. P. R., Indira, V. V. S., Manikanta, P., \&Srinivas, D. M. (2019). Large Scale Farming Analysis with the Help of IOT \& Data Analytics. International Journal of Advanced Multidisciplinary Scientific Research (IJAMSR), 2(3), 27-39.

[63] Rasooli, M. W., Bhushan, B., \& Kumar, N. (2020). Applicability of wireless sensor networks \& IoT in saffron \& wheat crops: A smart agriculture perspective. Int. J. Scientifi c Technol. Res, 9(2), 2456-2461.

[64] Pini, M., Marucco, G., Falco, G., Nicola, M., \& De Wilde, W. (2020). Experimental Testbed and Methodology for the Assessment of RTK GNSS Receivers Used in Precision Agriculture. IEEE Access, 8(1), 14690-14703.

[65] Saad, A., \& Gamatié, A. (2020). Water Management in Agriculture: A Survey on Current Challenges and Technological Solutions. IEEE Access, 8(1), 38082-38097.

[66] Gupta, M., Abdelsalam, M., Khorsandroo, S., \& Mittal, S. (2020). Security and privacy in smart farming: Challenges and opportunities. IEEE Access, 8(1), 34564-34584. 
[67] Liu, R., Zhang, Y., Ge, Y., Hu, W., \& Sha, B. (2020). Precision Regulation Model of Water and Fertilizer for Alfalfa Based on Agriculture Cyber-Physical System. IEEE Access, 8(1), 38501-38516.

[68] Gulec, O., Haytaoglu, E., \& Tokat, S. (2020). A Novel Distributed CDS Algorithm for Extending Lifetime of WSNs With Solar Energy Harvester Nodes for Smart Agriculture Applications. IEEE Access, 8(12), 58859-58873.

[69] Huang, K., Shu, L., Li, K., Yang, F., Han, G., Wang, X., \& Pearson, S. (2020). Photovoltaic Agricultural Internet of Things Towards Realizing the Next Generation of Smart Farming. IEEE Access, 8(22), 76300-76312.

[70] Balamurugan, S., Divyabharathi, N., Jayashruthi, K., Bowiya, M., Shermy, R. P., \& Shanker, R. (2016). Internet of agriculture: Applying IoT to improve food and farming technology. International Research Journal of Engineering and Technology (IRJET), 3(10), 713-719.

[71] Himesh, S., Prakasa Rao, E. V. S., Gouda, K. C., Ramesh, K. V., Rakesh, V., \& Mohapatra, G. N. (2018). Digital revolution and Big Data: a new revolution in agriculture. CAB Rev, 13(21), 1-7.

[72] Corcoran, P. (2014). Smartphones and the Internet of Servants [Notes from the Editor]. IEEE Consumer Electronics Magazine, 3(4), 4-9.

[73] Soman, S., Byju, G., \& Bharathan, R. (2013). GIS based decision support system for precision farming of cassava in India. ActaBiologicaIndica, 2(2), 394-399.

[74] Shekhar, S., Schnable, P., LeBauer, D., Baylis, K., \& Waal, K. V. (2017). Agriculture Big Data (AgBD) Challenges and Opportunities from Farm to Table: A Midwest Big Data Hub Community Whitepaper. White paper for the US National Institute of Food and Agriculture, 1-12.

[75] Morota, G., Ventura, R. V., Silva, F. F., Koyama, M., \& Fernando, S. C. (2018). Big data analytics and precision animal agriculture symposium: machine learning and data mining advance predictive big data analysis in precision animal agriculture. Journal of animal science, 96(4), 1540-1550.

[76] Astill, J., Dara, R. A., Fraser, E. D., \& Sharif, S. (2018). Detecting and predicting emerging disease in poultry with the implementation of new technologies and big data: a focus on Avian Influenza Virus. Frontiers in veterinary science, 5(2), 1-12.

[77] Kheyfets, B. A., \& Chernova, V. Y. (2019). Sustainable agriculture in Russia: Research on the dynamics of innovation activity and labor productivity. Entrep. Sustain, 7(6), 814-824.

[78] Shekhar, S., Colletti, J., Muñoz-Arriola, F., Ramaswamy, L., Krintz, C., Varshney, L., \& Richardson, D. (2017). Intelligent infrastructure for smart agriculture: An integrated food, energy and water system. 1(1), 1-8.

[79] Lee, S. W., Sarp, S., Jeon, D. J., \& Kim, J. H. (2015). Smart water grid: the future water management platform. Desalination and Water Treatment, 55(2), 339-346.

[80] Böröcz, M., Szöke, L., \& Horváth, B. (2016). Possible climate friendly innovation ways and technical solutions in the agricultural sector for 2030. Hungarian Agriculture System, 29(11), 55-59.

[81] Sanders, K. T., \& Masri, S. F. (2016). The energy-water agriculture nexus: the past, present and future of holistic resource management via remote sensing technologies. Journal of Cleaner Production, 117(23), 73-88.

[82] Mekonnen, Y., Burton, L., Sarwat, A., \& Bhansali, S. (2018, October). IoT sensor network approach for smart farming: An application in food, energy and water system. In 2018 IEEE Global Humanitarian Technology Conference (GHTC) 1-5. IEEE.

[83] Burton, L., Dave, N., Fernandez, R. E., Jayachandran, K., \& Bhansali, S. (2018). Smart gardening IoT soil sheets for real-time nutrient analysis. Journal of The Electrochemical Society, 165(8), B3157. 
[84] Gayatri, M. K., Jayasakthi, J., \& Mala, G. A. (2015, July). Providing Smart Agricultural solutions to farmers for better yielding using IoT. In 2015 IEEE Technological Innovation in ICT for Agriculture and Rural Development (TIAR) 40-43. IEEE.

[85] Gondchawar, N., \& Kawitkar, R. S. (2016). IoT based smart agriculture. International Journal of advanced research in Computer and Communication Engineering, 5(6), 838-842.

[86] hadoop.apache.org. (2020). Hadoop HDFS Architecture [online] Available at: https://hadoop.apache.org/docs/current/hadoop-project-dist/hadoop-hdfs/images/hdfsarchitecture.png. [Accessed 10 March. 2020].

[87] Shahzadi, R., Tausif, M., Ferzund, J., \& Suryani, M. A. (2016). Internet of things based expert system for smart agriculture. International Journal of Advanced Computer Science and Applications, 7(9), 341-350.

[88] Jawad, H. M., Nordin, R., Gharghan, S. K., Jawad, A. M., \& Ismail, M. (2017). Energy-efficient wireless sensor networks for precision agriculture: A review. Sensors, 17(8), 1781-1790.

[89] Suma, N., Samson, S. R., Saranya, S., Shanmugapriya, G., \& Subhashri, R. (2017). IOT based smart agriculture monitoring system. International Journal on Recent and Innovation Trends in computing and communication, 5(2), 177-181.

[90] a4academics.com. (2020). Hadoop-Mapreduce-Architecture [online] Available at: http://a4academics.com/images/hadoop/Hadoop-Mapreduce-Architecture.png [Accessed 9 March. 2020].

[91] Aithal, P. S., (2016). Study on ABCD Analysis Technique for Business Models, Business Strategies, Operating Concepts \& Business Systems. International Journal in Management and Social Science, 4(1), 98-115.

[92] Aithal, P. S., Shailashree, V., \& Kumar, P. M. (2015). A new ABCD technique to analyze business models \& concepts. International Journal of Management, IT and Engineering, 5(4), 409-423. 